Sharif University of Technology
Scientia Iranica
Transactions E: Industrial Engineering
hCIENTIA

\title{
Cooperative cellular manufacturing system: A cooperative game theory approach
}

\author{
M. Tavanayi ${ }^{\mathrm{a}}$, A. Hafezalkotob ${ }^{\mathrm{a}, *}$, and J. Valizadeh ${ }^{\mathrm{b}}$ \\ a. Industrial Engineering College, South Tehran Branch, Islamic Azad University, Tehran, Iran. \\ b. Department of Management, Saveh Branch, Islamic Azad University, Saveh, Iran. \\ Received 21 January 2018; received in revised form 30 October 2019; accepted 18 January 2020
}

\author{
KEYWORDS \\ Cell formation \\ problem; \\ Cellular \\ manufacturing \\ system; \\ Multi plants; \\ Cooperative game \\ theory; \\ Cost saving.
}

\begin{abstract}
In the cellular industry, the components of products are manufactured by multiple companies that are distributed across different regions, hence increasing production costs. In this regard, the present study aims to introduce a cooperative cellular manufacturing system to decrease these costs. To this end, a mathematical programming model was proposed to estimate the production cost in the case of companies working independently, and the model was then extended to consider coalitional conditions in which the companies cooperated as an integrated cell formation system. A key question that arises in this scenario is how to arrange the cells and machines of multiple companies when their cell formation systems are designed cooperatively. Through a realistic case study of three high-tech suppliers of Mega Motor Company, we demonstrated that these companies could reduce the costs using a cooperative cellular manufacturing system. Then, the cost savings of each coalition of companies obtained from cooperation was computed to get a fair allocation of the cost savings among the cooperating firms. Four cooperative game theory methods including Shapley value, $\tau$-value, core-center, and least core were then proposed to examine fair sharing of cost saving. A comprehensive analysis of the case study revealed significant managerial insights.
\end{abstract}

(C) 2021 Sharif University of Technology. All rights reserved.

\section{Introduction}

Nowadays, a typical production process involves construction, manufacturing, and supply activities, which are distributed among different geographical locations [1]. Cooperative production processes between these activities are being increasingly preferred when potential benefits are large. For instance, a change in the economic atmosphere and reduced sales of automotive Iranian companies have motivated the thought process

\footnotetext{
*. Corresponding author.

E-mail addresses: mahyatavanayi@gmail.com (M. Tavanayi); a_hafez@azad.ac.ir (A. Hafezalkotob); jabervalizadeh@stu.iau-saveh.ac.ir (J.Valizadeh)
}

doi: $10.24200 /$ sci. 2020.50315 .1629 on how the production cost can be reduced by reorganizing the dependent facilities that operate in the same region. Assume that a large automobile company manages several smaller companies that produce different parts using Cellular Manufacturing System (CMS). If these companies cooperate in the production processes and share their free capacities, the costs involved may be reduced.

When companies decide to form coalitions, answers to the two following questions gain significance: (i) How can the machines be arranged in the cells to minimize the production costs? and (ii) How should the Cost Saving (CS) be allocated among the companies in a fair manner?

To give an idea of the research problem at hand, a case study of the suppliers of the Mega Motor Company was selected. This company produces engines, 


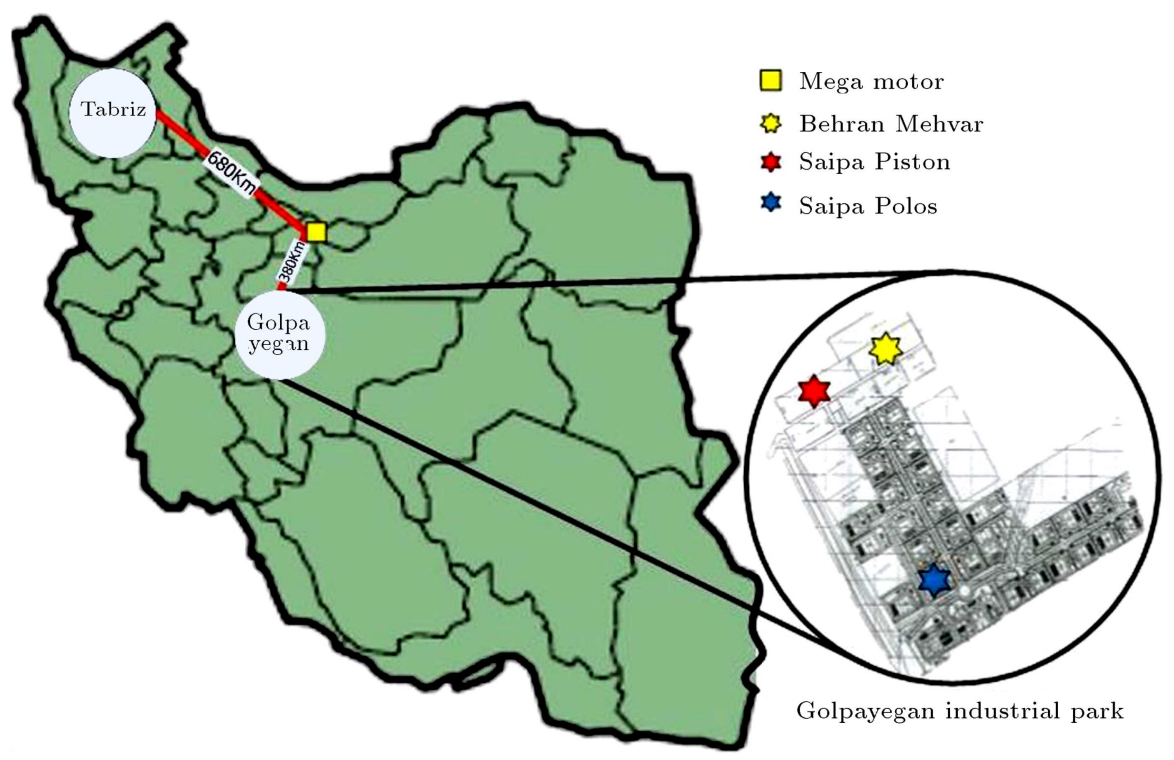

Figure 1. Locations of the companies.

gearboxes, and axles for the main Iranian automotive enterprises. In addition, the cooperation opportunity of the three following companies was studied: Behran-Mehvar, Saipa-Piston, and Saipa-Polos that manufacture similar products by adopting the Cellular Manufacturing (CM) technology and operate in the region of Golpayegan industrial park, Isfahan, Iran. These companies cater to a considerable proportion (in total $87 \%$ ) of different piston demands of the Mega Motor Company. Another company that is located in Tabriz, Saipa Azarbayejan competes with these companies and supplies $13 \%$ of the demands which is far from these three companies. Figure 1 illustrates the company locations on the map. Distance wise, Golpayegan is $380 \mathrm{~km}$ away from Tehran while Tabriz is situated $680 \mathrm{~km}$ away from Tehran. Evidently, the cost and time of transportation are greater for Saipa Azarbayejan and from Mega Motor's point of view, getting supplies from Golpayegan is certainly much more economical. Further, Behran-Mehvar, SaipaPiston, and Saipa-Polos have several CNC machines with free capacities. If these companies cooperate and share the machine capacities, they can cover the supply contribution from Saipa Azarbayejan. In this respect, in Cooperative Game Theory (CGT), four challenging questions need to be answered [2]:

1. How can the profit of participants be computed in a cooperative environment?

2. How should the extra profit obtained from the cooperation be fairly divided among the participants?

3. How should the intra-cell material handling cost be reduced?
4. How should the inter-cell material handling cost be reduced?

The rest of this paper is organized as follows. Section 2 reviews the related researches. Prerequisites and assumptions of the proposed models are defined in Section 3. The proposed models are described in the non-coalitional condition in Subsection 3.1 and in the coalitional condition in Subsection 3.2. Section 4 provides a real case study of the cooperation problem between suppliers of the Mega Motor Company as well as the methods for cost-saving allocation supported on CGT. Section 5 presents the contributions of this study along with some suggestions for the future researches.

\section{Literature review}

This study is mainly concerned with two issues: blood supply chain and CGT. Therefore, a full review of the literature on these topics is provided in the following sections.

\subsection{Survey on $C M S$}

$\mathrm{CM}$ is a method for the manufacturing process in which each manufacturing cell is composed of a group of machine tools. In a CMS, the machine tools used to process a family of parts are joined together to form a cell. CM has the flexibility of job shops in addition to the high production rate of flow lines [3]. The main objective of $\mathrm{CM}$ is to obtain the required flexibility to manufacture a high diversity of products with medium demand while keeping high productivity of large-scale production. Numerous studies have mentioned the benefits of implementing a cellular production system. To be specific, it reduces parts preparation time, inventory during manufacturing, and cost and time 
of material displacement and it improves production planning $[4,5]$.

Several studies have considered inter- and intracell material handling in static conditions. Dimopoulos and Zalzala [6] introduced a method for determining job assignment for each operation, layout of the cells in the job shop, layout of the machines within the cells, and transportation system design. Akturk and Turkcan [7] solved a mixed integer programming model, considering the superseded layout, routing, cell size, minor utilization, and low-profit level constraints. Their model enjoys certain advantages in terms of production volumes, processing times, and operation sequences. Mahdavi and Mahadevan [8] presented an algorithm to specify the layout of the machines within each cell and machine groups as well as the part families simultaneously. Recent studies have concentrated on the inter- and/or intra-cell material handling in a dynamic production environment (i.e., Dynamic Cellular Manufacturing System (DCMS)). Defersha and Chen [9] established a mathematical programming model for cell configuration according to the tooling requirements of parts and machines. Their model offers certain features such as dynamic cell configuration, alternative routings, machine capacity, and operation and setup costs. Ahkioon et al. [10] focused on arranging CMSs by considering multi-period production planning, operation sequence, machine capacity, and machine procurement. Kia et al. [11] studied a multi-floor layout design and proposed a mixed-integer programming model for a dynamic environment. The idea behind their model was to determine Cell Formation (CF) and Group Layout (GL) in a multi-period planning horizon simultaneously. Kia et al. [12] also developed a mixed-integer non-linear programming model for DCMS in which the products and part demands might change during the planning horizon.

Tavakkoli Moghaddam et al. [13] established a new mathematical model to evaluate the facility layout problem in CMS when the demands were stochastic. In their study, minimization of inter- and intra-cell material handling costs was regarded as an objective function. Wang et al. [14] formulated a new mathematical model for CMS that considers demand changes over a product's lifecycle. The objective function of the proposed model was to minimize inter- and intra- material handling costs. Wang and Sarker [15] suggested a Quadratic Assignment Problem (QAP) for the layout of machine-cells to minimize the inter-cell material handling cost. Bagheri and Bashiri [16] presented a new mathematical programming model that could provide a solution to the $\mathrm{CF}$, operator assignment, and inter-cell layout problems simultaneously. They considered minimization of the costs of inter- and intra-cell part handling, reallocation of the machines, relocation, and operators as the objective functions. Chen and Cao [17] suggested an integrated model to determine times to begin part-processing decisions. Their model minimizes the sum of costs of inter-cell material handling and manufacturing cell construction. Safaei et al. [18] considered a sequence of operations, alternative process plans, and machine replication and presented a mixed-integer programming model by assuming a dynamic environment. The objective function of the model was to minimize the summation of the interand intra-cell material handling and reconfiguration costs in addition to the machine constant and variable costs. Similarly, for DCMS, Mahdavi et al. [19] developed an integer non-linear mathematical programming model that incorporated hiring and firing of workers, worker assignments, and workers' available time. The objective function of the model was to minimize the summation costs of inter-cell material handling, reconfiguration of the machines, hiring, firing, and salary issues as well as holding and backorder. An integrated mathematical model was introduced by Safaei and Tavakkoli-Moghaddam [20] that could minimize machine costs, inter/intra-cell movement, reconfiguration, partial subcontracting, and inventory carrying costs. Saidi-Mehrabad and Safaei [21] employed a neural network approach to solve the problem of dynamic production $\mathrm{CF}$ with the objective of minimizing the cost of reinstallation, fixed cost, and machine change by considering multiple paths and replicating machines. Schaller [22] proposed a linear integer model for the CF problem with the objective of minimizing the cost of producing parts, constant cost of the machine, and cost of moving the machine and solved it using an extended banned search algorithm. Table 1 examines some of the previous researches more closely.

However, all of these studies have attempted to design cellular production systems to minimize intercellular displacements and optimal alignment. This attempt makes it only part of the optimization of the system, which reduces the cost and operation time and increases productivity. According to the findings of this study, the ability to collaborate with several manufacturing companies at the same time while considering the conditions of the alliance can reduce total cost, organize the cells and machines of different companies, and achieve better solutions. The reviewed studies presented different models for CMS; however, none of them considered designing CMS for multiple cooperating companies. The CF problem for one company, discussed in the present study, is somewhat similar to that mentioned by Kia et al. [11]; in other words, the intra- and inter-cell material handling costs and determined demands are similar in both models. The CGT concept was applied in another dimension to the model by considering multiple independent companies that may form coalitions in 
Table 1. The publications related to the cellular manufacturing systems.

\begin{tabular}{|c|c|c|c|c|c|c|c|c|c|c|}
\hline \multirow[b]{2}{*}{ Authors } & \multirow[b]{2}{*}{ Year } & \multicolumn{2}{|c|}{ Model type } & \multicolumn{3}{|c|}{ Approaches } & \multicolumn{2}{|c|}{ Objective } & \multicolumn{2}{|c|}{ Solving method } \\
\hline & & $\begin{array}{c}\text { Single } \\
\text { objective }\end{array}$ & $\begin{array}{c}\text { Multi } \\
\text { objective }\end{array}$ & Concurrent & Sequential & Cooperative & $\begin{array}{c}\text { Handling } \\
\text { cost }\end{array}$ & $\begin{array}{c}\text { Inter cell } \\
\text { cost }\end{array}$ & Exact & $\begin{array}{c}\text { Meta- } \\
\text { heuristic }\end{array}$ \\
\hline Kia et al. [12] & 2012 & * & & * & & & & * & * & * \\
\hline $\begin{array}{l}\text { Tavakkoli Moghaddam } \\
\text { et al. [13] }\end{array}$ & 2007 & $*$ & & & * & & * & & $*$ & \\
\hline Wang et al. [14] & 2001 & $*$ & & * & & & $*$ & & & $*$ \\
\hline Wang and Sarker [15] & 2002 & $*$ & & $*$ & & & $*$ & & $*$ & $*$ \\
\hline Bagheri and Bashiri [16] & 2014 & $*$ & & $*$ & & & & $*$ & * & \\
\hline Chen and Cao [17] & 2004 & $*$ & & $*$ & & & & $*$ & & $*$ \\
\hline Safaei et al. [18] & 2008 & $*$ & & & * & & $*$ & $*$ & & $*$ \\
\hline Mahdavi et al. [19] & 2010 & $*$ & & * & & & $*$ & $*$ & $*$ & \\
\hline $\begin{array}{l}\text { Saidi-Mehrabad and } \\
\text { Safaei }[21]\end{array}$ & 2007 & $*$ & & $*$ & & & * & & $*$ & \\
\hline Schaller $[22]$ & 2007 & $*$ & & & * & & $*$ & & & \\
\hline Frisk et al. [23] & 2010 & $*$ & & * & & & $*$ & & & $*$ \\
\hline $\begin{array}{l}\text { Hafezalkotob and } \\
\text { Makui [25] }\end{array}$ & 2015 & $*$ & & & * & & * & * & & $*$ \\
\hline Lozano et al. [24] & 2013 & & * & * & & & $*$ & & & $*$ \\
\hline Current research & 2021 & $*$ & & & $*$ & $*$ & $*$ & * & * & \\
\hline
\end{tabular}

a dynamic environment and reduce their production costs.

\subsection{Survey on CGT and its applications}

Game theory is categorized into two groups of CGT and Non-Cooperative Game Theory (NCGT). In CGT, players are able to cooperate to create value by forming coalitions; however, they do not compete to obtain further value [21]. Under some circumstances, through binding agreements, the players cooperate with each other and organize the coalition. In the real world, the most obvious and common agreements between companies are formal legal contracts. In CGT, there are some players who form a coalition together. There is also a function called the characteristic function that denotes the game value of each coalition. The characteristic function incorporates an input to the solution concept which returns the value captured by each player (their imputation).

Several researchers have previously utilized CGT to analyze problems such as routing and scheduling, forest transportation planning, logistics network, process planning, and production problems. Frisk et al. [23] investigated a forest transportation planning problem and evaluated different CGT methods for distributing cost-saving among the cooperating companies. Lozano et al. [24] established a linear transportation model for determining CSs when different companies merge their transportation requirements. Through CGT approach, they calculated CS achievable by the companies. Hafezalkotob and Makui [25] presented a robust optimization model to deal with the multipleowner logistic network problem and answered the question regarding how independently owners of a network should cooperate to obtain a reliable maximum flow.
Mohebbi and Li [26] evaluated costs, shadow prices, and volume weights to distribute the total cost or savings among the members. Zibaei et al. [27] adopted CGT methods such as the Shapley value, $\tau$-value, and maximin core to evaluate the CS opportunity of cooperation in a multi-depot vehicle routing problem.

Sakawa et al. [28] formulated a mathematical programming model to minimize the production and transportation cost in a cooperative environment. They assumed that the companies could make multiple products in different regions. They considered two important items: capacities of companies and demand in regions. They employed this model in a housing material manufacturing case study and applied the CGT to obtain a fair cost allocation. Curiel et al. [29] considered the cost allocation problem under one machine-scheduling problem. Mohammaditabar et al. [30] concentrated on capacitated-supplier selection in a supply chain using inventory related costs. They proposed different CGT methods such as Shapley value, $\tau$-value, and least core for profit allocation among the members of a supply chain. Some other investigations are reviewed in Table 2.

\subsection{Research gap and contributions}

Although cooperative production is a favorable strategy in the real world to reduce production costs and increase profit, a few studies have mathematically formulated a cooperative production strategy.

Previous researchers have proposed different models for the problem of CM, but to the best of the authors' knowledge, no study has considered how the CM problem should be modeled when multiple companies with the CM technology decide to cooperate together. We call this system Cooperative Cellular 
Table 2. The review table of the game theory in research dimensions.

\begin{tabular}{|c|c|c|c|c|c|c|c|c|c|}
\hline \multirow[b]{2}{*}{ Articles } & \multirow[b]{2}{*}{ Year } & \multirow[b]{2}{*}{$\begin{array}{c}\text { Profit } \\
\text { allocation }\end{array}$} & \multirow[b]{2}{*}{$\begin{array}{c}\text { Reduce } \\
\text { costs }\end{array}$} & \multicolumn{3}{|c|}{ Research dimensions } & \multicolumn{3}{|c|}{ Utilization } \\
\hline & & & & $\begin{array}{c}\text { Production } \\
\text { planning }\end{array}$ & $\begin{array}{c}\text { Inventory } \\
\text { planning }\end{array}$ & $\begin{array}{c}\text { Inventory } \\
\text { management }\end{array}$ & $\begin{array}{c}\mathrm{Co}- \\
\mathrm{CMS}\end{array}$ & Pricing & Production \\
\hline Fardi et al. [38] & 2019 & $*$ & & & $*$ & $*$ & & & \\
\hline Zhang et al. [39] & 2019 & * & & * & & & & * & \\
\hline Baogui and Minghe [40] & 2017 & & & $*$ & & & & & $*$ \\
\hline Cellini and Lambertini [41] & 2007 & * & & $*$ & & * & & & \\
\hline René et al. [42] & 2018 & * & & & * & * & & & \\
\hline Nazari et al. [43] & 2017 & $*$ & & & $*$ & * & & & \\
\hline Fiestras-Janeiro et al. [44] & 2011 & & & & * & * & & & \\
\hline Gutierrez et al. [45] & 2019 & $*$ & & $*$ & & & & & $*$ \\
\hline He et al. [46] & 2018 & & & & & & & & * \\
\hline Ghashghaei and Mozafari. [47] & 2019 & * & & $*$ & & & & * & \\
\hline Le et al. [48] & 2018 & & & & & & & & * \\
\hline Wu et al. [49] & 2018 & & & & & * & & & \\
\hline Chao et al. [50] & 2018 & & & & & & & & * \\
\hline This research & 2021 & $*$ & $*$ & * & $*$ & & $*$ & & \\
\hline
\end{tabular}

Manufacturing System (Co-CMS). In Co-CMS, the agreements between companies depend on the costs to be saved when they cooperate and also the contribution of each firm to the total CS. Therefore, an analytical method for estimating the CSs and CS allocation should be adopted in Co-CMS, which is the main contribution of this study.

\section{Methodology}

Whenever a person (government or individuals) attempts to do something in the face of others, his or her action may provoke the other party into these interactions when both parties are aware of their effects. Now, players may agree on a strategy to choose among many options while playing the game. If the agreement between the players is enforceable and practicable, they call the game "cooperative". If the agreement between the players is not enforceable and practical, they call it "non-cooperative". In other words, in case players can act based on the agreed principles, the game will be regarded as cooperative.

In cooperative models, it is assumed that all players work together to achieve optimal results for the system. Thus, in collaborative models, the problem is transformed from multi-decision and multi-criteria to single-decision and multi-criteria. Such a similarity, according to game theory experts, provides the researchers with a better understanding and helps them understand these models rather than non-cooperative models. Unlike CGT which analyzes the actions and reimbursement of individual players, CGT examines the joint actions and collective reimbursement of a group of players (or coalitions). While reviewing the literature of transportation, one important question that CGT is concerned with is how to allocate costs or benefits among players in a fair way. Therefore, this system is stable and does not give players an incentive to leave the coalition [31]. Accordingly, in the proposed model of this research, decision-makers' objective functions are merged, and a hybrid goal function is created to transform the problem from multi-objective to single-objective.

The models for both non-cooperative and cooperative conditions (i.e., Models (1)-(10) and (11)-(21), respectively) should be solved first for the companies. The optimal value for the objective function may represent the characteristic function of CGT which is the total production cost of a company (or cooperating companies). The cooperation will be advantageous for companies if they obtain reasonable CS out of coproduction. When the cooperation is reasonable, CS can be fairly distributed by some solution methods of CGT such as Shapley value, core center, $\tau$-value, least core, and Equal Cost Saving Method (ECSM). Figure 2 illustrates the Co-CMS methodology.

\subsection{Mathematical models}

In this section, a nonlinear mixed-integer programming model for the Co-CMS problem is presented with the objective of minimizing the total costs of inter- and intra-cell material handling and intra-factory material handling. The idea is to develop the model first by considering the objective costs of $\mathrm{CF}$ by each company independently and then, for a coalition of the companies with CMS technology, i.e., Co-CMS. Here, Co-CMS is acceptable for cooperating companies if the optimal objective function in the cooperative scenario is lower than the sum of the individual minimum objective function costs (inter- and intra-cell material handling, intra-company material handling, and benefits from increased production) for the members of that 


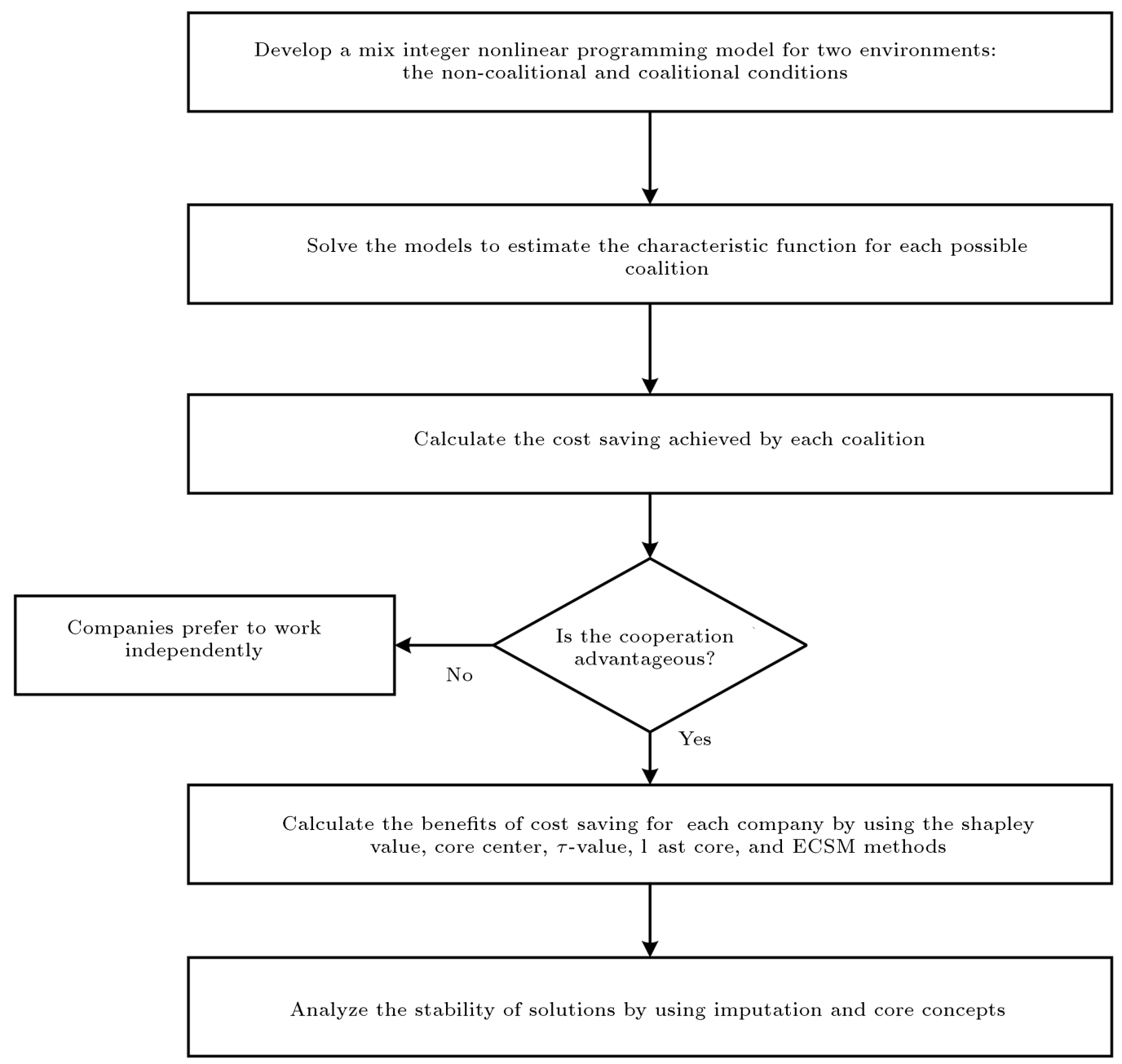

Figure 2. Overview of the Cooperative Cellular Manufacturing System (Co-CMS) based on the Cooperative Game Theory (CGT).

coalition. Then, the model results were elaborated by evaluating the Co-CMS in a real cooperative environment for the suppliers of the Mega Motor Company.

\subsubsection{Mathematical model in the non-coalition condition}

In this section, we develop a mathematical model for CMS to determine the objective costs and cell arrangements when companies work independently. As mentioned earlier, the first step is to solve this model for each company independently and, then, develop a model for all coalitions between two companies in the next section. Then, the model is solved for all coalitions among three companies and so on until a grand coalition is achieved. We make the following assumptions to establish the CMS model for multiple companies in non-coalition conditions:

Assumption 1. All operations of the products of a company should be processed in the factory of that company. Moreover, the demand for products of a company should be satisfied by the production of that company;

Assumption 2. The companies produce similar products. Moreover, the production process is assumed to be the same for each company. The companies may not use the same machines, but the machines are multi-functional, which means that each operation for a product can be conducted on different machines with different processing times. This feature is called alternative process routing that makes flexibility in the process plan of the products [11];

Assumption 3. The CMS problem of multiple companies is considered under a deterministic condition. Therefore, the number of companies and locations are known in advance. The product demand for each company is also identified in advance. The capacity of all machines and processing time of each product are predetermined. Moreover, the processing cost of each operation of a product is identified beforehand; 
Assumption 4. The cells in the plants are not physically separated. Indeed, the cell configuration is determined through the layout of a plant and it influences the material handling routes of semi-finished products;

Assumption 5. The inter- and intra- cell handling costs are different. To be specific, the inter- and intra-cell handling costs of semi-finished products are contingent upon the distance travelled. Therefore, the location of machine in cells and location of cells in the plant affect the handling costs of products;

Assumption 6. The maximum and minimum values are dependent on the cell sizes which are known in advance. In other words, there exist lower and upper bounds for all types of machines that can be located on the shop floor. However, the shape of cells is determined by the model in order to bear minimum inter- and intra-cell handling costs.

The indices, parameters, and variables of the model are listed in the following:

\section{Indices}

$P \quad$ Index set of products

$M \quad$ Index set of machines

$L \quad$ Index set of location

C Index set of cells

$k_{p} \quad$ Index set of operation indices for product $p$

$t c_{m} \quad$ Available time capacity for machine $m$

$d_{p} \quad$ Demand for product $p$

$t_{k p m} \quad$ Processing time of operation $k$ on machine $m$ for each product $p$

$a_{k p m} \quad 1$ if the operation $k$ of product $p$ can be processed on machine $m$, otherwise, 0

$d i c_{l l^{\prime}} \quad$ The distance between two locations $l$ and $l^{\prime}$

IE Inter-cell material handling cost for product $p$ per unit of distance

$I A \quad$ Intra-cell material handling cost for product $p$ per unit of distance

$x_{k p m} \quad$ The number of product $p$ processed by operation $k$ on machine $m$

$w_{m l c} \quad 1$ if machine $m$ is located at location $l$ and assigned to cell $c$, otherwise, 0

$y_{\text {kpmm }} \quad$ The number of product $p$ processed by operation $k$ on machine $m$ and moved to machine $m^{\prime}$.

The following model is used to obtain the objective costs of each company when companies work independently. This formulation is derived from the study of Kia et al. [11] and is given as:

$$
\begin{aligned}
\operatorname{Min} z= & \sum_{c} \sum_{m} \sum_{l} \sum_{m^{\prime}, m \neq m^{\prime}} \sum_{l^{\prime}, l^{\prime} \neq l} \sum_{p} \sum_{k} \\
& w_{m l c} w_{m^{\prime} l^{\prime} c} y_{k p m m^{\prime}} d i c_{l l^{\prime}} E+\sum_{c} \sum_{c^{\prime}, c \neq c^{\prime}} \\
& \sum_{m} \sum_{l} \sum_{m^{\prime}, m \neq m^{\prime}} \sum_{l^{\prime}, l^{\prime} \neq l} \sum_{p} \sum_{k} \\
& w_{m l c} w_{m^{\prime} l^{\prime} l^{\prime}} y_{k p m m^{\prime}} \operatorname{dic}_{l l^{\prime}} I A,
\end{aligned}
$$

subject to:

$$
\begin{array}{ll}
x_{k p m} \leq a_{k p m} M, & \forall k \quad \forall p \quad \forall m, \\
\sum_{m} x_{k=1, p m} \geq d_{p}, & \forall p \quad \forall k, \\
\sum_{m} \sum_{l} \sum_{c} w_{m l c} \leq L, & \\
\sum_{m} \sum_{l} \sum_{c} w_{m l c} \geq 1, & \forall m, \\
\sum_{p} \sum_{k} x_{k p m} t_{k p m} \leq t c_{m}, & \forall k \quad \forall p \quad \forall m, \\
x_{k p m}=\sum_{m^{\prime}} y_{k p m m^{\prime}}, & \forall k \quad \forall p \quad \forall m, \\
x_{k p m^{\prime}}=\sum_{m} y_{k-1 p m m^{\prime}}, & \forall l, \\
\sum_{c} \sum_{m} w_{m l c} \leq 1, & \forall m .
\end{array}
$$

Objective Function (1) comprises two parts: the first part indicates the intra-cell material handling cost and the second part indicates the inter-cell material handling cost. Constraint (2) ensures that each operation of a part is performed on the machine that is able to perform that operation. The demand satisfaction condition for all parts is guaranteed by Constraint (3). Constraint (4) states that the total number of machines of all types utilized in the shop floor should not be larger than value $L$. Constraint (5) states that at least one machine of all types should be used on the shop floor. Constraint (6) is the capacity limitation constraint of each machine, stating that when machine type $m$ is used, the total processing time of this machine should not be greater than its time capacity. 
Material flow conservation conditions are ensured by Constraint (7) and (8). Constraint (9) is to guarantee that each location can be simultaneously occupied at most by one machine. Constraint (10) shows that each machine should only belong to one location of a cell.

3.1.2. Mathematical model in the coalitional condition In Co-CMS, the cooperating companies should identify the arrangement of machines in the cells and production process of products to evaluate the production cost of the entire system. We now develop a mathematical model to calculate the optimal cost of Co-CMS. First, prerequisites and assumptions should be defined, as shown in the following:

\section{Prerequisites and assumptions}

Assumptions 2-7 of CMS in the non-coalition environment are also considered in Co-CMS. Moreover, the following assumptions are introduced to establish the framework of the Co-CMS model:

Assumption 1. The operations of a company product can be processed in the factory of cooperating companies. Moreover, the demand for the products of a company can be satisfied by the production of other cooperating companies;

Assumption 2. In case semi-finished products are transferred between factories of cooperating companies, the intra-factory material handling cost is incurred by the coalition. The intra-factory material handling cost depends on the distance traveled. Therefore, the location of factories directly affects the total cost of Co-CMS. The handling costs among cooperating factories should not be too high compared to CM costs. Otherwise, the high handling costs among factories diminish synergy of cooperation and the players may withdraw from the Co-CMS.

\section{Indices}

$P \quad$ Index set of the products

$F \quad$ Index set of the factories

$M_{f} \quad$ Index set of the machine indices for factory $f$

$k_{p} \quad$ Index set of the operation indices for product $p$

$c_{f} \quad$ Index set of the cell indices for factory $f$

$l_{f} \quad$ Index set of the location indices for factory $f$

\section{Model parameters}

$t c_{m} \quad$ Available capacity for machine $m$

$d_{p f} \quad$ Demand for product $p$ in factory $f$ $d d_{p f} \quad$ Demand for product $p$ in factory $f$ if the factories cooperate together

$t_{k p m} \quad$ Processing time of operation $k$ on machine $m$ for each product $p$

$a_{k p m} \quad 1$ if operation $k$ of product $p$ can be processed on machine $m$, otherwise, 0

$p v_{m f} \quad 1$ if machine $m$ belongs to factory $f$, otherwise, 0

$p i_{l f} \quad 1$ if location $l$ belongs to factory $f$, otherwise, 0

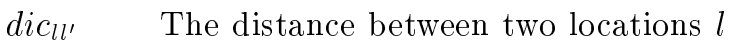
and $l^{\prime}$

IE Inter-cell material handling costs for product $p$ per unit of distance

IA Intra-cell material handling costs for product $p$ per unit of distance

IT Intra-factory material handling costs for product $p$ per unit of distance

sav $_{p} \quad$ Profit from selling of product $p$

\section{Variables}

$w_{m l c} \quad 1$ if machine $m$ is located at location $l$ and assigned to cell $c$, otherwise, 0

$y_{k p m m^{\prime}} \quad$ The number of products $p$ processed by operation $k$ on machine $m$ and transferred to machine $m^{\prime}$

$x_{k p m} \quad$ The number of products $p$ processed by operation $k$ on machine $m$

In a coalitional condition, the companies with excess capacities can cooperate together by sharing these capacities. When two or more companies cooperate together, the intra-factory costs should be added to the basic model. On the contrary, the companies can reduce their overload costs upon increasing the production rate. Therefore, the benefit from increased production is added to the objective function. This factor has a reverse effect on the total costs. The final model is given, as shown in the following:

$$
\begin{aligned}
\operatorname{Min} z= & \sum_{f} \sum_{c \in c_{f}} \sum_{m \in m_{f}} \sum_{l \in l_{f}} \sum_{m^{\prime} \in m_{f}, m \neq m^{\prime}} \sum_{l^{\prime} \in l_{f}, l^{\prime} \neq l} \\
& \sum_{p} \sum_{k} w_{m l c} w_{m^{\prime} l^{\prime} c} y_{k p m m^{\prime}} d i c_{l l^{\prime}} I E \\
& +\sum_{f} \sum_{c \in c_{f}} \sum_{c^{\prime} \in c_{f}, c \neq c^{\prime}} \sum_{m \in m_{f}} \sum_{l \in l_{f}} \sum_{m^{\prime} \in m_{f}, m \neq m^{\prime}} \\
& \sum_{l^{\prime} \in l_{f}, l^{\prime} \neq l} \sum_{p} \sum_{k} w_{m l c} w_{m^{\prime} l^{\prime} c^{\prime}} y_{k p m m^{\prime}} d i c_{l l^{\prime}} I A \\
& +\sum_{f} \sum_{f^{\prime}, f \neq f^{\prime}} \sum_{c \in c_{f}} \sum_{c^{\prime} \in c_{f}, c \neq c^{\prime}} \sum_{m \in m_{f}} \sum_{l \in l_{f}}
\end{aligned}
$$




$$
\begin{gathered}
\sum_{m^{\prime} \in m_{f}, m \neq m^{\prime}} \sum_{l^{\prime} \in l_{f}, l^{\prime} \neq l} \sum_{p} \sum_{k} \\
w_{m l c} w_{m^{\prime} l^{\prime} c^{\prime}} y_{k p m m^{\prime}} d i c_{l l^{\prime}} I T \\
+\sum_{p} \sum_{f}\left(d_{p f}-d 1_{p f}\right) s a v_{p}
\end{gathered}
$$

subject to:

$$
\begin{aligned}
& x_{k p m} \leq a_{k p m} M, \\
& \sum_{m} x_{k=1, p m} \geq \sum_{f} d d_{p f}, \quad \forall k \quad \forall p \quad \forall m, \\
& p \quad \forall k, \sum_{m \in m_{f}} \sum_{l \in l_{f}} \sum_{c \in c_{f}} w_{m l c} \leq l_{f}, \quad \forall f, \\
& \sum_{m \in m_{f}} \sum_{l \in l_{f}} \sum_{c \in c_{f}} w_{m l c} \geq 1, \quad \forall f, \\
& \sum_{p} \sum_{k} x_{k p m} t_{k p m} \leq t c_{m}, \quad \forall m, \quad \forall k \quad \forall p \quad \forall m, \\
& x_{k p m}=\sum_{m^{\prime}} y_{k p m m^{\prime}}, \\
& \sum_{k p m^{\prime}}=\sum_{m} y_{k-1 p m m^{\prime}}, \quad \forall c \in f \quad \forall m \quad \forall l . \\
& \sum_{c \in c_{f}} \sum_{m \in m} \sum_{m} w_{m l c} \leq 1, \\
& w_{m l c}=1, \\
& \forall v_{m f} p i_{l f}, \\
& \forall p \quad \forall m^{\prime},
\end{aligned}
$$

Objective Function (11) minimizes the sum of inter- and intra-cell material handling costs as well as the intra-factory material handling cost, considering the benefits achievable from increased production to reduce the manufacturing overload costs. Constraint (12) ensures that each operation of a product is processed on the machine that can process that operation. The demand satisfaction conditions for all products are guaranteed by Constraint (13). Inequalities (14) and (15) necessitate that the number of machines used on the shop floor is less than that of the existing locations on the shop floor that it is greater than 1 . Constraint (16) shows machine capacity constraints, while Constraints (17) and (18) preserve the material flow conservation equations. Constraints (19) and (20) certify that at a same time, each location can gain one machine at most and only belongs to one cell. Constraint (21) guarantees that a machine is allowed to be placed at a location if and only if the machine and location both belong to the same factory.

To linearize Models (11)-(21), we employ a procedure used by Kia et al. [11] and apply the following changes. The non-negative variables $y y_{k p m l m^{\prime} l^{\prime} c}$ and $y y_{k p m l m^{\prime} l^{\prime} c^{\prime}}$ are introduced to the following equations:

$$
\begin{aligned}
& w_{m l c} w_{m^{\prime} l^{\prime} c} y_{k p m m^{\prime}}=y y_{k p m l m^{\prime} l^{\prime} c}, \\
& w_{m l c} w_{m^{\prime} l^{\prime} c^{\prime}} y_{k p m m^{\prime}}=y y_{k p m l m^{\prime} l^{\prime} c^{\prime}} .
\end{aligned}
$$

Therefore, the following constraints are added to the basic model:

$$
\begin{aligned}
& y y_{k p m l m^{\prime} l^{\prime} c} \geq y_{k p m m^{\prime}}-M\left(2-w_{m l c}-w_{m^{\prime} l^{\prime} c}\right) \\
& \forall \mathrm{k} \forall p \forall m, m^{\prime} \neq m \in m_{f} \forall l, l^{\prime} \neq l \in l_{f}, \\
& \forall c \in c_{f} \forall f, \\
& y y_{k p m l m^{\prime} l^{\prime} c^{\prime}} \geq y_{k p m m^{\prime}}-M\left(2-w_{m l c}-w_{m^{\prime} l^{\prime} c^{\prime}}\right) \\
& \forall \mathrm{k} \forall p \forall m, m^{\prime} \neq m \in m_{f} \forall l, l^{\prime} \neq l \in l_{f} \\
& \forall c, c^{\prime} \neq c \in c_{f} \forall f .
\end{aligned}
$$

The linearization helps solve the model by linear programming package. Now, the first model should be solved to achieve the objective cost for the companies when they work independently and, then, evaluate the objective function for all possible coalitions. At the end, the share of each company in CS is determined by such methods as Shapley value and core center.

The model is developed through incorporation of the intra factory costs to the objective function. Each company determines its capacity of sale and production. When companies cooperate, they can increase their production capacity, but not more than the sale capacity. Therefore, the maximum range of production is sale capacity. Moreover, according to the concept of economy of scale, an increase in the production volume can decrease the final overhead costs and cost of production. Hence, the difference between the quantity of production before and after the cooperation results in less production cost. This factor will be considered as the objective function.

\subsection{CGT approach}

In this section, we now evaluate the problem of how to distribute the CS resulting from the cooperation among different companies. This problem exists in several real-world situations where the independent companies are capable of co-operating in order to reduce the cost of their activities. This problem should be addressed with regard to the contribution of each company in different possible coalitions. In addition, CGT is an appropriate approach to tackling this problem that 
provides a general framework to evaluate the costsaving allocation problems [24,25]. By evaluating all possible coalitions of the cooperating companies, CGT provides a set of methods for distributing the obtained CS in a fair manner. Some basic concepts and methods related to CGT are briefly reviewed in the following (for more details, see [23-25,32]).

In CGT, the players have an incentive to cooperate if their cooperation leads to sufficient synergy. According to the supper additive property of CGT, the optimal cost function for any coalitional situation should be lower than the total individual optimum cost function of the coalition members [24]. In Co-CMS, the cost-savings of Co-CMS should justify the cooperation. This point is mathematically expressed as:

$$
T C(S) \leq \sum_{j \in S} T C(j) .
$$

The difference between the minimum cost of coalition $S$ and summation of individual minimum costs reflects the CSs of that coalition [24], $C S(S)$, that is:

$$
C S(S)=\sum_{j \in S} T C(\{j\})-T C(S) .
$$

The cost-saving should be estimated by the cost of the cooperating companies. Consequently, similar to $[24,25]$, the synergy of a coalition can be defined as:

$$
\operatorname{Synergy}(S)=\frac{C S(S)}{T C(S)}
$$

Several methods have been proposed in CGT; however, the main focus was put on the Shapley value, least core [33], $\tau$-value [34], core center [35], and ECSM $[21,25,27]$ in this study.

Shapley [36] developed a CGT method for distributing payoff of cooperation based on expected marginal contribution of each player in different coalitions. Four axioms of efficiency, symmetry, additive, and dummy property are included in Shapley method [37]. In Co-CMS, based on the cost-saving of coalitions, the Shapley value determines CS of each cooperating company, as shown in the following:

$$
\begin{aligned}
y_{j}= & \sum_{S \in N, j \in S} \frac{(|S|-1) !-(|N|-|S|) !}{|N| !} \\
& {[C S(S)-C S(S-j)], }
\end{aligned}
$$

where $|S|$ denotes the number of participants in coalition $S$. The value of $C S(S)-C S(S-j)$ represents the amount by which the cost of coalition $S-j$ increases when participant $j$ joins it. The Shapley value assigns CS to each company by calculating the sum of the marginal contribution of that company over all possible coalitions.
The core embraces an important concept in CGT and represents the set of feasible assignments that cannot be enhanced by any coalition of the players. The core of a cooperative game can be denoted by:

$$
\begin{aligned}
\text { core }(0) & =\{\vec{y} \in Y \mid e(S, \vec{y}) \leq 0, \forall S \subset P\} \\
& =\left\{\vec{y} \in Y \mid C S(S) \leq \sum_{j \in S} y_{j}, \forall S \subset P\right\} .
\end{aligned}
$$

The game is stable if and only if the core is nonempty. Moreover, for real number $\varepsilon, \varepsilon$-core is as follows:

$$
\text { core }(\varepsilon)=\{\vec{y} \in Y \mid e(S, \vec{y}) \leq \varepsilon, \forall S \subset P, S \neq P, S \neq \phi\} \text {. }
$$

The first $\varepsilon$ value for which $\operatorname{core}(\varepsilon) \neq \phi$ is named the least core. The least core (or the minimax core) can be obtained from the following linear programming problem:

$\operatorname{Min} \varepsilon$,

subject to :

$$
e(S, \vec{y})=\nu(S)-\sum_{j \in S} y_{j} \leq \varepsilon, \text { for all } S \subset P, S \neq P .
$$

ECSM is a novel allocation method based on equal profit method developed by Frisk et al. [23]. ECSM provides similar relative CS for manufacturing companies. It minimizes the maximum difference in pairwise CS of the companies. The linear programming problem of ECSM is formulated as follows:

$\operatorname{Min} \lambda$,

subject to :

$$
\begin{aligned}
& \lambda \geq\left|z_{i}-z_{j}\right|, \quad \forall(i, j) \in K, \\
& \sum_{i \in S} z_{i} \geq C S(S), \quad \text { for all } S \subset K, S \neq P, \\
& \sum_{i \in P} z_{i}=C S(P) .
\end{aligned}
$$

According to the first constraint, the variable $\lambda$ is the largest difference between cost-saving assignments that should be minimized in the objective function. According to the second and third constraints, the solution of ESCM should belong to the core space so that it can ensure a stable solution.

In CGT, $\tau$-value is an important method that is composed of the upper vector $M(K, C S)$ and lower vector $m(K, C S)$. In addition, $M_{k}$ is the $k$ th coordinate of $M(K, C S)$ that represents the maximum right value for player $k$ from the grand coalition. Furthermore, $m_{k}$ is the $k$ th coordinate of $m(K, C S)$ that represents the minimum right value for player $k$ from grand coalition. 


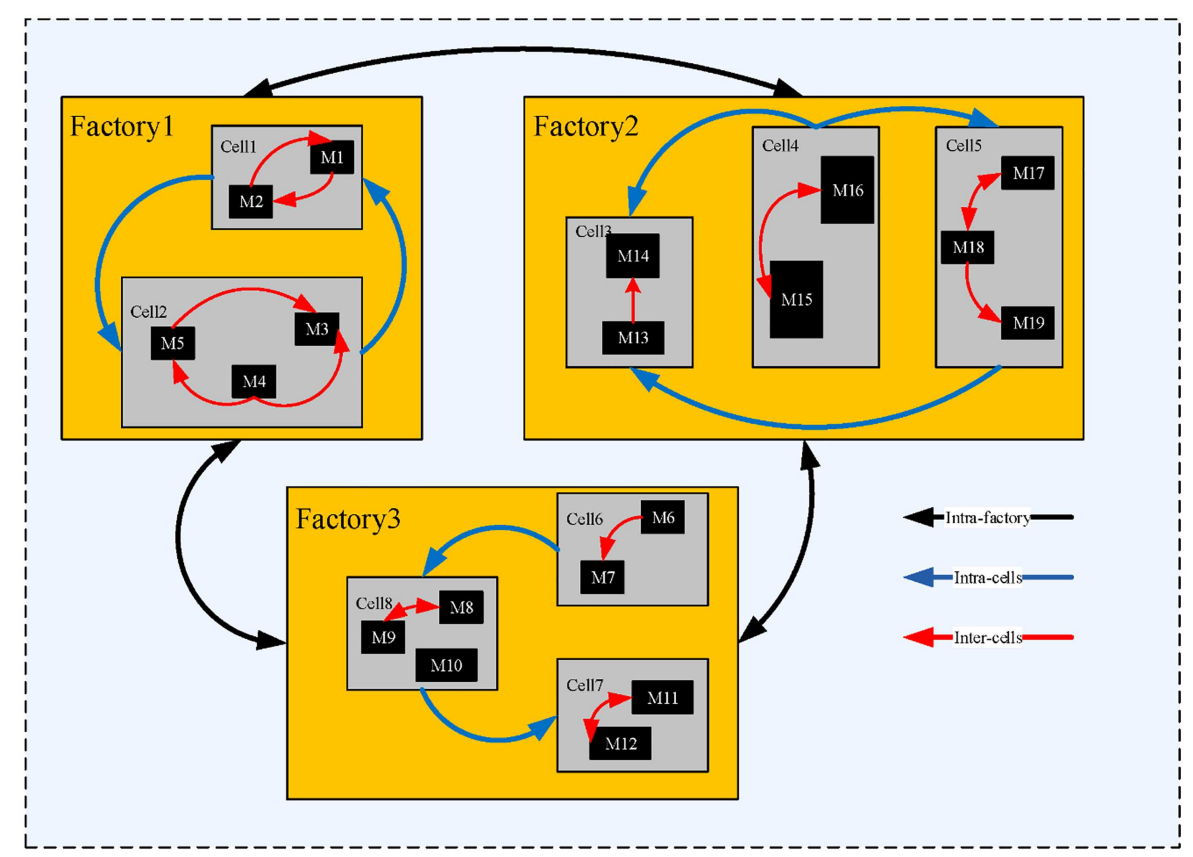

Figure 3. The three factories with the cell formation framework in cooperation with each other.

For the cost-saving value of cooperating companies, $M_{k}$ and $m_{k}$ are formulated as follows:

$$
\begin{aligned}
& M_{k}=C S(K)-C S(K \backslash\{k\}), \\
& m_{k}=\max _{S_{m}: k^{\prime} \in S_{m}}\left\{C S\left(S_{m}\right)-\sum_{k^{\prime} \in S_{m} \backslash\{k\}} M_{k^{\prime}}\right\} .
\end{aligned}
$$

In Co-CMS, $M_{k}$ and $m_{k}$ represent the maximum and minimum rights of cost-saving allocation for company $k$. The $\tau$-value method computes imputation based on $M(K, C S)$ and $m(K, C S)$ as follows:

$$
\tau_{k}=m_{k}+\alpha\left(M_{k}-m_{k}\right),
$$

where $\alpha \in[0,1]$ can be uniquely evaluated through $\sum_{k \in K} \tau_{k}=C S(K)$.

In the next section, we employ these methods of CGT in the case study of Co-CMS for the Mega Motor Company.

\section{Case study}

The Mega Motor Company sees its mission in improving the general property and sustainable development through designing and manufacturing power train for the automotive industry by means of advanced technology. Mega Motor gets the supplies of pistons for internal combustion engines from four main companies: Behran-Mehvar, Saipa-Piston, Saipa-Polos, and Saipa Azarbayejan. Mega Motor provides these suppliers with raw materials (i.e., alloy ingots named LM13) at a certain rate and purchases products thereafter. Therefore, each supplier company has a specific contribution to supply Mega Motor's demand of pistons. A piston is a significant component of internal combustion engines that transforms the energy obtained from fuel combustion in a cylinder into beneficial mechanical power. Manufacturing process of piston includes five steps: casting, heat treatment, machining process, pin fitting, and inspection. The machining process contains three steps: drilling, grinding, and reaming. The four suppliers perform these steps by different high-tech CNC machines. The suppliers try to increase their benefit by controlling their overload costs, especially the transformation costs. If the companies can meet greater portion of the product demand, they could reduce their overload costs.

We evaluate Co-CMS of three suppliers, i.e., Behran-Mehvar, Saipa-Piston, and Saipa-Polos, which operate in Golpayegan industrial park (see Figure 1). These suppliers are called f1, f2, and f3. Figure 3 shows how these companies with the CMS framework can cooperate. According to Figure 3, when the companies form a coalition, three types of transportation costs are incurred including inter- and intra-cell material handling costs and intra-factory transfer cost.

The data such as the distances between locations, machines capacities, characteristics of machines performance, and financial data are real. The detailed data for the grand coalition are given in Table 3. A numerical example of the mathematical programming model has been solved in all possible coalitions of the three companies. Table 4 lists the important decision variables of each coalition $(\{\mathrm{f} 1, \mathrm{f} 2\},\{\mathrm{f} 1, \mathrm{f} 3\},\{\mathrm{f} 2, \mathrm{f} 3\}$, 
Table 3. Parameters of the numerical example (the detailed data of the grand collation of the factories).

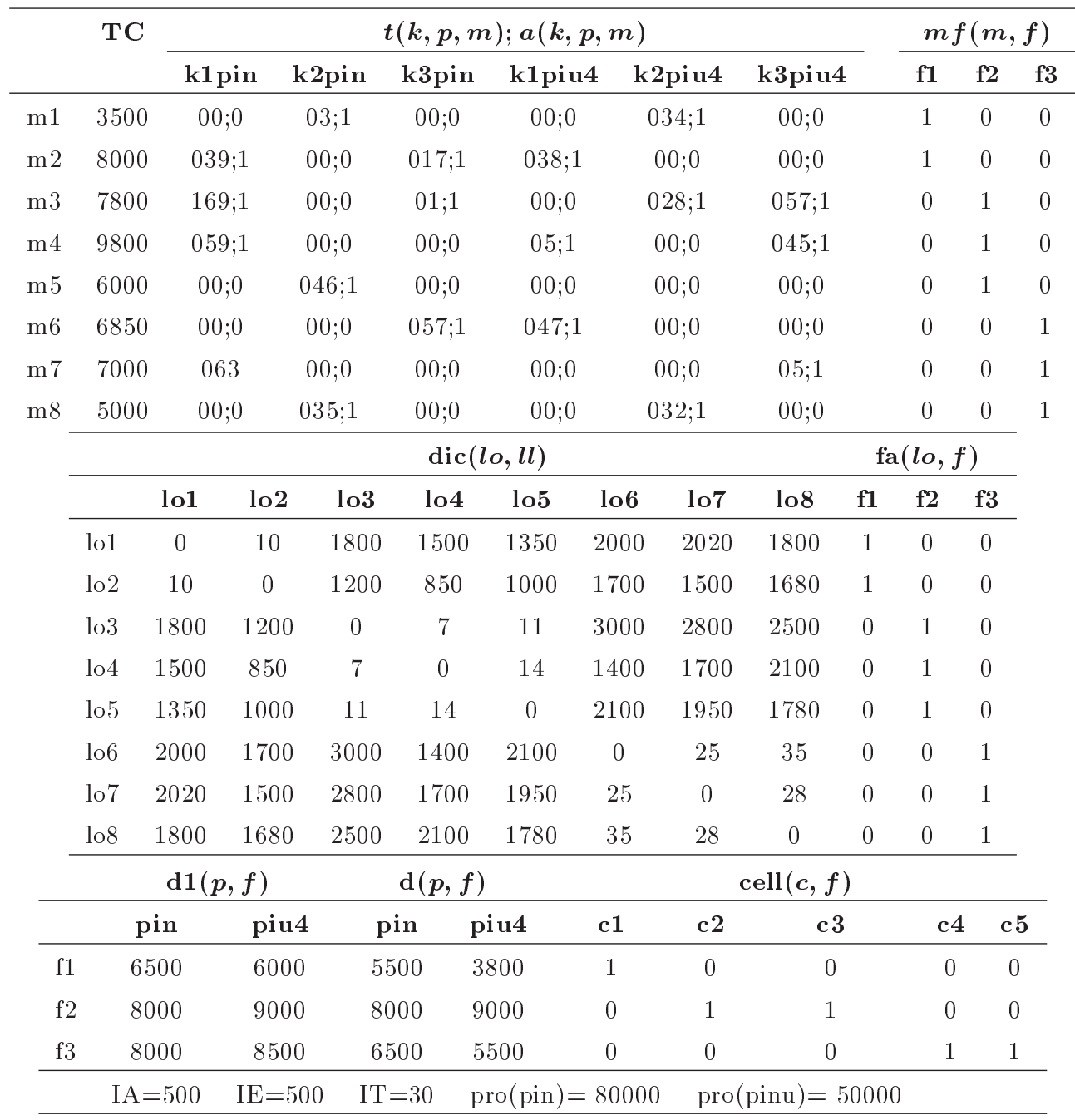

Table 4. Two important variables of numerical example, $y$ number of the products transferred between the machines, and $w$ machine allocation in the cells.

\begin{tabular}{|c|c|c|c|c|c|c|c|c|c|c|c|c|c|c|c|}
\hline \multicolumn{4}{|c|}{ Coalition $\{f 1, f 2\}$} & \multicolumn{4}{|c|}{ Coalition $\{\mathbf{f} 1, \mathbf{f} 3\}$} & \multicolumn{4}{|c|}{ Coalition $\{\mathrm{f} 2, \mathrm{f} 3\}$} & \multicolumn{4}{|c|}{ Coalition $\{\mathrm{f} 1, \mathrm{f} 2, \mathrm{f} 3\}$} \\
\hline \multicolumn{2}{|c|}{$y\left(k, p, m, m^{\prime}\right)$} & \multicolumn{2}{|c|}{$w(m, l, c)$} & \multicolumn{2}{|c|}{$y\left(k, p, m, m^{\prime}\right)$} & \multicolumn{2}{|c|}{$w(m, l, c)$} & \multicolumn{2}{|c|}{$y\left(k, p, m, m^{\prime}\right)$} & \multicolumn{2}{|c|}{$w(m, l, c)$} & \multicolumn{2}{|c|}{$y\left(k, p, m, m^{\prime}\right)$} & \multicolumn{2}{|l|}{$w(m, l, c)$} \\
\hline $\mathrm{k} 1 \mathrm{pin} \mathrm{m} 2 \mathrm{~m} 1$ & 1,457 & $\mathrm{~m} 1 \mathrm{lo} 2 \mathrm{c} 1$ & 1 & $\mathrm{k} 1$ pin $\mathrm{m} 2 \mathrm{~m} 1$ & 11,666 & $\mathrm{~m} 1 \mathrm{lo} 1 \mathrm{c} 1$ & 1 & $\mathrm{k} 1 \mathrm{pin} \mathrm{m} 3 \mathrm{~m} 5$ & 1,083 & $\mathrm{~m} 3 \mathrm{lo} 4 \mathrm{c} 3$ & 1 & $\mathrm{k} 1$ pin $\mathrm{m} 2 \mathrm{~m} 1$ & 5,056 & $\mathrm{~m} 1 \mathrm{lol} \mathrm{c} 1$ & 1 \\
\hline $\mathrm{k} 1$ pin $\mathrm{m} 2 \mathrm{~m} 5$ & 1,511 & $\mathrm{~m} 2 \operatorname{lo} 1 \mathrm{c} 1$ & 1 & $\mathrm{k} 1$ pin $\mathrm{m} 2 \mathrm{~m} 8$ & 1,643 & $\mathrm{~m} 2 \operatorname{lo} 2 \mathrm{c} 1$ & 1 & $\mathrm{k} 1$ pin $\mathrm{m} 4 \mathrm{~m} 5$ & 11,960 & $\mathrm{~m} 4 \mathrm{lo5} \mathrm{c} 3$ & 1 & $\mathrm{k} 1$ pin $\mathrm{m} 2 \mathrm{~m} 5$ & 13,043 & $\mathrm{~m} 21 \circ 2 \mathrm{c} 1$ & 1 \\
\hline $\mathrm{k} 1$ pin $\mathrm{m} 4 \mathrm{~m} 5$ & 11,532 & $\mathrm{~m} 3 \mathrm{lo} 4 \mathrm{c} 2$ & 1 & $\mathrm{k} 1$ pin $\mathrm{m} 7 \mathrm{~m} 8$ & 1,191 & $\mathrm{~m} 6 \operatorname{lo} 6 \mathrm{c} 4$ & 1 & $\mathrm{k} 1$ pin $\mathrm{m} 7 \mathrm{~m} 8$ & 2,957 & $\mathrm{~m} 5 \mathrm{lo} 3 \mathrm{c} 2$ & 1 & $\mathrm{k} 1$ pin $\mathrm{m} 2 \mathrm{~m} 8$ & 139 & $\mathrm{~m} 31 \circ 3 \mathrm{c} 2$ & 1 \\
\hline $\mathrm{k} 1$ piu $4 \mathrm{~m} 2 \mathrm{~m} 1$ & 9,008 & $\mathrm{~m} 4 \mathrm{lo} 3 \mathrm{c} 2$ & 1 & $\mathrm{k} 1$ piu $4 \mathrm{~m} 6 \mathrm{~m} 8$ & 12,500 & $\mathrm{~m} 7 \operatorname{lo} 8 \mathrm{c} 4$ & 1 & $\mathrm{k} 1$ piu $4 \mathrm{~m} 4 \mathrm{~m} 3$ & 5,487 & m6lo6c5 & 1 & $\mathrm{k} 1$ pin $\mathrm{m} 4 \mathrm{~m} 1$ & 162 & $\mathrm{~m} 4 \mathrm{lo} 5 \mathrm{c} 3$ & 1 \\
\hline $\mathrm{k} 1$ piu $4 \mathrm{~m} 4 \mathrm{~m} 3$ & 5,992 & $\mathrm{~m} 5 \mathrm{lo} 5 \mathrm{c} 3$ & 1 & $\mathrm{k} 2$ pin $\mathrm{m} 1 \mathrm{~m} 2$ & 11,666 & $\mathrm{~m} 81 \circ 7 \mathrm{c} 5$ & 1 & $\mathrm{k} 1$ piu $4 \mathrm{~m} 6 \mathrm{~m} 3$ & 1 & $\mathrm{~m} 7 \mathrm{lo} 8 \mathrm{c} 5$ & 1 & $\mathrm{k} 1$ pin $\mathrm{m} 7 \mathrm{~m} 8$ & 4,100 & m5lo4c3 & 1 \\
\hline $\mathrm{k} 2$ pin $\mathrm{m} 1 \mathrm{~m} 2$ & 214 & & & $\mathrm{k} 2$ pin $\mathrm{m} 8 \mathrm{~m} 2$ & 1,124 & & & $\mathrm{k} 1 \mathrm{piu} 4 \mathrm{~m} 6 \mathrm{~m} 8$ & 10,012 & $\mathrm{~m} 81 \mathrm{lo} 7 \mathrm{c} 4$ & 1 & $\mathrm{k} 1$ piu $4 \mathrm{~m} 4 \mathrm{~m} 3$ & 12,666 & m6lo6c4 & 1 \\
\hline $\mathrm{k} 2$ pin $\mathrm{m} 1 \mathrm{~m} 3$ & 1,243 & & & $\mathrm{k} 2$ pin $\mathrm{m} 8 \mathrm{~m} 6$ & 1,710 & & & $\mathrm{k} 2$ pin $\mathrm{m} 5 \mathrm{~m} 3$ & 13,043 & & & $\mathrm{k} 1$ piu $4 \mathrm{~m} 6 \mathrm{~m} 8$ & 8,834 & $\mathrm{~m} 7 \mathrm{lo} 8 \mathrm{c} 4$ & 1 \\
\hline $\mathrm{k} 2$ pin $\mathrm{m} 5 \mathrm{~m} 3$ & 13,043 & & & $\mathrm{k} 2$ piu $4 \mathrm{~m} 8 \mathrm{~m} 2$ & 1 & & & $\mathrm{k} 2$ pin $\mathrm{m} 8 \mathrm{~m} 6$ & 2,957 & & & $\mathrm{k} 2$ pin $\mathrm{m} 1 \mathrm{~m} 2$ & 5,218 & $\mathrm{~m} 8 \mathrm{lo} 7 \mathrm{c} 5$ & 1 \\
\hline $\mathrm{k} 2 \mathrm{piu} 4 \mathrm{~m} 1 \mathrm{~m} 2$ & 6,766 & & & $\mathrm{k} 2$ piu $4 \mathrm{~m} 8 \mathrm{~m} 7$ & 12,499 & & & $\mathrm{k} 2 \mathrm{piu} 4 \mathrm{~m} 3 \mathrm{~m} 3$ & 5,488 & & & $\mathrm{k} 2$ pin $\mathrm{m} 5 \mathrm{~m} 3$ & 13,043 & & \\
\hline $\mathrm{k} 2 \mathrm{piu} 4 \mathrm{~m} 1 \mathrm{~m} 3$ & 2,242 & & & $\mathrm{k} 3$ pin $\mathrm{m} 2 \mathrm{~m} 2$ & 12,790 & & & $\mathrm{k} 2 \mathrm{piu} 4 \mathrm{~m} 8 \mathrm{~m} 7$ & 10,012 & & & $\mathrm{k} 2$ pin $\mathrm{m} 8 \mathrm{~m} 6$ & 4,239 & & \\
\hline $\mathrm{k} 2$ piu $4 \mathrm{~m} 3 \mathrm{~m} 3$ & 5,992 & & & $\mathrm{k} 3$ pin $\mathrm{m} 6 \mathrm{~m} 6$ & 1,710 & & & $\mathrm{k} 3$ pin $\mathrm{m} 3 \mathrm{~m} 3$ & 13,043 & & & $\mathrm{k} 2 \mathrm{piu} 4 \mathrm{~m} 3 \mathrm{~m} 3$ & 5,174 & & \\
\hline $\mathrm{k} 3$ pin $\mathrm{m} 2 \mathrm{~m} 2$ & 214 & & & $\mathrm{k} 3$ piu $4 \mathrm{~m} 2 \mathrm{~m} 2$ & 1 & & & $\mathrm{k} 3$ pin $\mathrm{m} 6 \mathrm{~m} 6$ & 2,957 & & & $\mathrm{k} 2 \mathrm{piu} 4 \mathrm{~m} 3 \mathrm{~m} 4$ & 7,492 & & \\
\hline $\mathrm{k} 3$ pin $\mathrm{m} 3 \mathrm{~m} 3$ & 14,286 & & & $\mathrm{k} 3$ piu $4 \mathrm{~m} 7 \mathrm{~m} 7$ & 12,499 & & & $\mathrm{k} 3$ piu $4 \mathrm{~m} 3 \mathrm{~m} 3$ & 5,488 & & & $\mathrm{k} 2$ piu $4 \mathrm{~m} 8 \mathrm{~m} 7$ & 8,834 & & \\
\hline $\mathrm{k} 3$ piu $4 \mathrm{~m} 2 \mathrm{~m} 2$ & 6,766 & & & & & & & $\mathrm{k} 3$ piu $4 \mathrm{~m} 7 \mathrm{~m} 7$ & 10,012 & & & $\mathrm{k} 3$ pin $\mathrm{m} 2 \mathrm{~m} 2$ & 5,218 & & \\
\hline \multirow[t]{5}{*}{$\mathrm{k} 3$ piu $4 \mathrm{~m} 3 \mathrm{~m} 3$} & 8,234 & & & & & & & & & & & $\mathrm{k} 3$ pin $\mathrm{m} 3 \mathrm{~m} 3$ & 13,043 & & \\
\hline & & & & & & & & & & & & $\mathrm{k} 3$ pin $\mathrm{m} 6 \mathrm{~m} 6$ & 4,239 & & \\
\hline & & & & & & & & & & & & k3piu4m $3 \mathrm{~m} 3$ & 5,174 & & \\
\hline & & & & & & & & & & & & $\mathrm{k} 3$ piu $4 \mathrm{~m} 4 \mathrm{~m} 4$ & 7,492 & & \\
\hline & & & & & & & & & & & & $\mathrm{k} 3$ piu $4 \mathrm{~m} 7 \mathrm{~m} 7$ & 8,834 & & \\
\hline
\end{tabular}




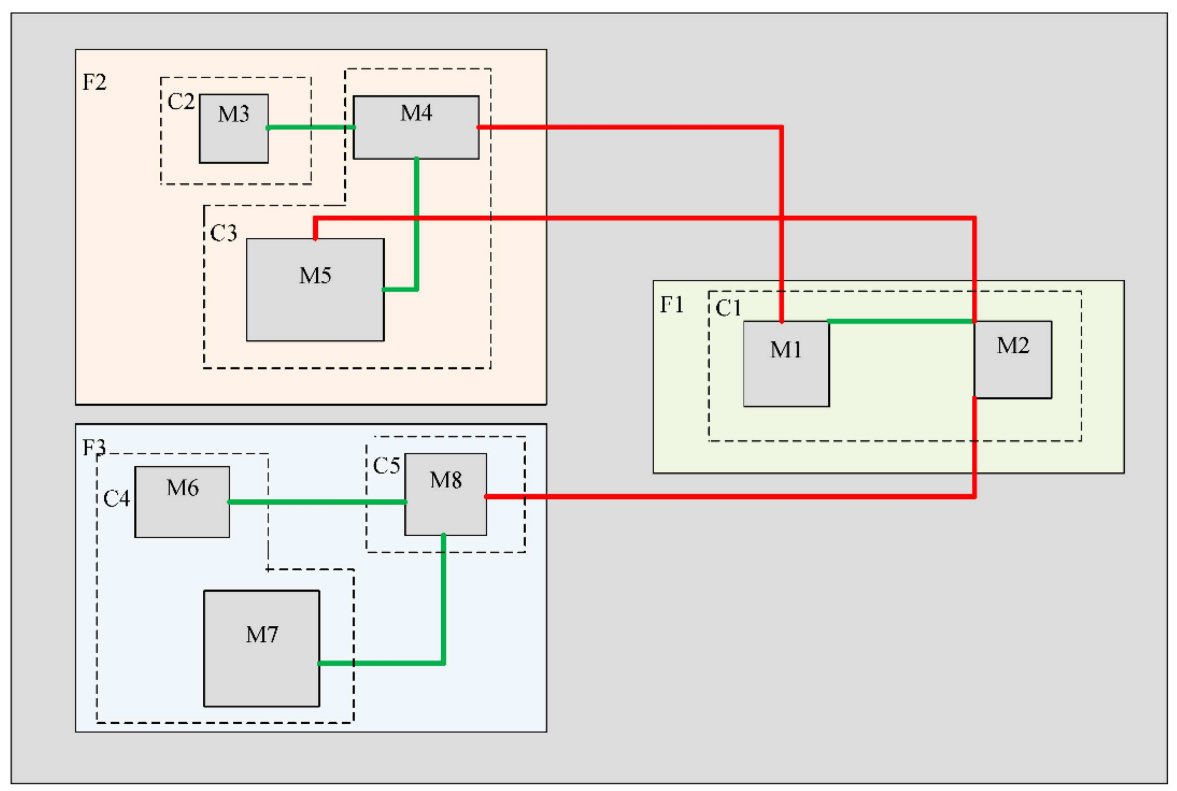

Figure 4. Transportation between different factories in Cooperative Cellular Manufacturing System (Co-CMS).

Table 5. Total cost, cost-saving, and synergy of all possible collations.

\begin{tabular}{cccc}
\hline Coalition $\boldsymbol{S}$ & $\boldsymbol{T C}(\boldsymbol{S})$ & $\boldsymbol{C S}(\boldsymbol{S})$ & Synergy $(\boldsymbol{S})$ \\
\hline$\{\mathrm{f} 1\}$ & $223,200,000$ & 0 & 0 \\
$\{\mathrm{f} 2\}$ & $135,493,500$ & 0 & 0 \\
$\{\mathrm{f} 3\}$ & $318,000,000$ & 0 & 0 \\
$\{\mathrm{f} 1, \mathrm{f} 2\}$ & $331,184,000$ & $27,509,500$ & 08 \\
$\{\mathrm{f} 1, \mathrm{f} 3\}$ & $367,165,000$ & $174,035,000$ & 47 \\
$\{\mathrm{f} 2, \mathrm{f} 3\}$ & $342,470,000$ & $111,023,500$ & 32 \\
$\{\mathrm{f} 1, \mathrm{f} 2, \mathrm{f} 3\}$ & $358,890,000$ & $317,803,500$ & 89 \\
\hline
\end{tabular}

and $\{\mathrm{f} 1, \mathrm{f} 2, \mathrm{f} 3\})$. Moreover, Figure 4 illustrates the $\mathrm{CF}$ structure of Co-CMS in the grand coalition of the three factories.

This case study was used to evaluate the performance of the CGT methods in fair allocation of cost-saving of Co-CMS. In the first step, the CSM models (1)-(10) should be solved for $\{\mathrm{f} 1\},\{\mathrm{f} 2\}$, and $\{\mathrm{f} 3\}$ and then, Co-CSM model needs to be solved for each possible coalition $S$, i.e., $\{\mathrm{f} 1, \mathrm{f} 2\},\{\mathrm{f} 1, \mathrm{f} 3\},\{\mathrm{f} 2, \mathrm{f} 3\}$, and $\{\mathrm{f} 1, \mathrm{f} 2, \mathrm{f} 3\}$. Table 5 illustrates the minimum total cost $T C(S)$ obtained from the optimum objective function of the models. Moreover, Table 5 shows the cost-saving and synergy of each coalition computed by Eqs. (27) and (28), respectively. The cost-saving is zero if a com- pany works independently, and the cost-savings and the synergies increase upon increasing the coalition size.

Based on the characteristic functions of CSs in Table 5, the cost-saving assignment methods can be evaluated based on the Shapley value, $\tau$-value, cores center, least core, and ECSM, as discussed in Section 3. The results of the methods are summarized in Table 6 . Further, Lingo 11 package was utilized to obtain an optimum solution to the least core problem (32) and ECSM problem (33). Other assignments of Table 6 are achieved based on TUGlab platform [35].

In this study, we first used the CGT to solve the problem of cellular production. Given the small dimensions of the problem in the case study investigated in the research and extracted real-world data, the optimal solution was obtained. In other words, the exact method of solving and modeling with Lingo helped us achieve an optimal solution in the shortest span of time.

Coalition $S$ is satisfied as the difference between the allocated cost-saving of each coalition and the total share of each company from the achieved cost-savings, i.e.:

$$
F_{s}(C S, y)=\sum_{p \in s} y_{p}-C S(S) \quad \forall S \neq \phi, S \subseteq N
$$

Table 6. Cost-saving assignment of Cooperative Cellular Manufacturing System (Co-CMS) based on Cooperative Game Theory (CGT) methods.

\begin{tabular}{cccccc}
\hline Factory & Shapley & $\boldsymbol{\tau}$-value & Core center & Least core & ECSM \\
\hline$\{\mathrm{f} 1\}$ & $102,520,000$ & $102,550,000$ & $102,910,000$ & $134,895,800$ & $105,934,500$ \\
$\{\mathrm{f} 2\}$ & $71,010,000$ & $71,300,000$ & $71,570,000$ & $71,884,250$ & $105,934,500$ \\
$\{\mathrm{f} 3\}$ & $144,270,000$ & $143,960,000$ & $143,320,000$ & $111,023,500$ & $105,934,500$ \\
\hline
\end{tabular}


Table 7 shows the satisfaction values, $F_{s}(C S, y)$, for coalition $S$ obtained from the aforementioned CGT methods and relative satisfaction with respect to coalition cost $T C(S)$ which is computed as $100 * F_{s}(C S, y) / T C(S)$. The obtained results revealed that the possibility of satisfying the coalitions would decrease upon increasing the coalition size. The minimum satisfaction among the coalitions for each solution is shown in the last row of Table 7 . The results showed that Shapley value, $\tau$-value, core center, and least core methods had the largest minimum relative satisfaction $(20 \%)$. The least satisfaction can be interpreted as a measure of the core centeredness of each solution and the minimum distance of the solution from the facets of the core boundary is stated [24]. It is also a simple measure of the degree of stability of each solution. According to Table 7 , the maximum least satisfaction in terms of $F_{s}(C S, y)$ corresponds to the least core method.

In this study, Mean Absolute Deviation (MAD) was utilized to measure the similarity between the five tested cost-savings allocation methods. It was computed through the following formula:

$$
M A D\left(\bar{y}, \bar{y}^{\prime}\right)=\frac{|N|}{C S(N)} \sum_{p}\left(\bar{y}-\bar{y}^{\prime}\right) .
$$

In Co-CMS, the MAD of the cost saving shares allocated to the different companies is presented in Table 8. From the MAD, we find that the Shapley, $\tau$-value, and core center methods produce similar solutions to the cost-saving allocation problem.

In this section, the imputation and core sets are graphically evaluated to obtain the solutions of the Shapley value, $\tau$-value, core-center, mini $\max$ core, and ECSM methods. For the Co-CMS of the three suppliers, Figure 5 depicts the core and imputation sets. All CGT solutions are also given in Figure 5. All solutions are stable imputations because they are located in the core set. From Figure 5, we also find that the Shapley value, $\tau$-value, and core-center methods present very close cost-saving assignments.

Figure 6 represents the sensitivity analysis of the Shapley value assignment in Co-CMS with respect to the intra-factory transportation cost of the first company (with the coefficient $\lambda$ ). The results revealed that the cost-saving assignment to the first company decreased as its transportation cost increased; however, the cost-saving assignments of the other companies remained almost unchanged. Furthermore, the figure shows that the cost-saving of the grand coalition also decreases. When the intra-factory cost increases, the subsequent reduction in the total cost-saving leads to

Table 7. Coalition satisfactions in Cooperative Cellular Manufacturing System (Co-CMS) for different Cooperative Game Theory (CGT) methods.

\begin{tabular}{|c|c|c|c|c|c|c|c|c|c|c|}
\hline Coalition $S$ & Shapley & $\%$ & $\tau$-value & $\%$ & Core center & $\%$ & Least core & $\%$ & ECSM & $\%$ \\
\hline$\{\mathrm{f} 1\}$ & $102,520,000$ & 46 & $102,550,000$ & 46 & $102,910,000$ & 46 & $134,895,800$ & 60 & $105,934,500$ & 47 \\
\hline$\{\mathfrak{f} 2\}$ & $71,010,000$ & 52 & $71,300,000$ & 53 & $71,570,000$ & 53 & $71,884,250$ & 53 & $105,934,500$ & 78 \\
\hline$\{\mathrm{f} 3\}$ & $144,270,000$ & 45 & $143,960,000$ & 45 & $143,320,000$ & 45 & $111,023,500$ & 35 & $105,934,500$ & 33 \\
\hline$\{\mathrm{f} 1, \mathrm{f} 2\}$ & $146,020,500$ & 44 & $146,340,500$ & 44 & $146,970,500$ & 44 & $179,270,550$ & 54 & $184,359,500$ & 56 \\
\hline$\{\mathrm{f} 1, \mathrm{f} 3\}$ & $72,755,000$ & 20 & $72,475,000$ & 20 & $72,195,000$ & 20 & $71,884,300$ & 20 & $37,834,000$ & 10 \\
\hline$\{\mathrm{f} 2, \mathrm{f} 3\}$ & $104,256,500$ & 30 & $104,236,500$ & 30 & $103,866,500$ & 30 & $71,884,250$ & 21 & $100,845,500$ & 29 \\
\hline Min & $71,010,000$ & 20 & $71,300,000$ & 20 & $71,570,000$ & 20 & $71,884,250$ & 20 & $37,834,000$ & 10 \\
\hline $\operatorname{Max}$ & $146,020,500$ & 52 & $146,340,500$ & 53 & $146,970,500$ & 53 & $179,270,550$ & 60 & $184,359,500$ & 78 \\
\hline Sum & $640,832,000$ & 238 & $640,862,000$ & 238 & $640,832,000$ & 238 & $640,842,650$ & 243 & $640,842,500$ & 254 \\
\hline
\end{tabular}

Table 8. The values of Mean Absolute Deviation (MAD).

\begin{tabular}{cccccc}
\hline MAD & Shapley & $\boldsymbol{\tau}$-value & Core center & Least core & ECSM \\
\hline Shapley & - & 001 & 002 & 63 & 72 \\
$\tau$-value & - & - & 001 & 62 & 72 \\
Core center & - & - & - & 61 & 71 \\
least core & - & - & - & - & 64 \\
ECSM & - & - & - & - & - \\
\hline
\end{tabular}




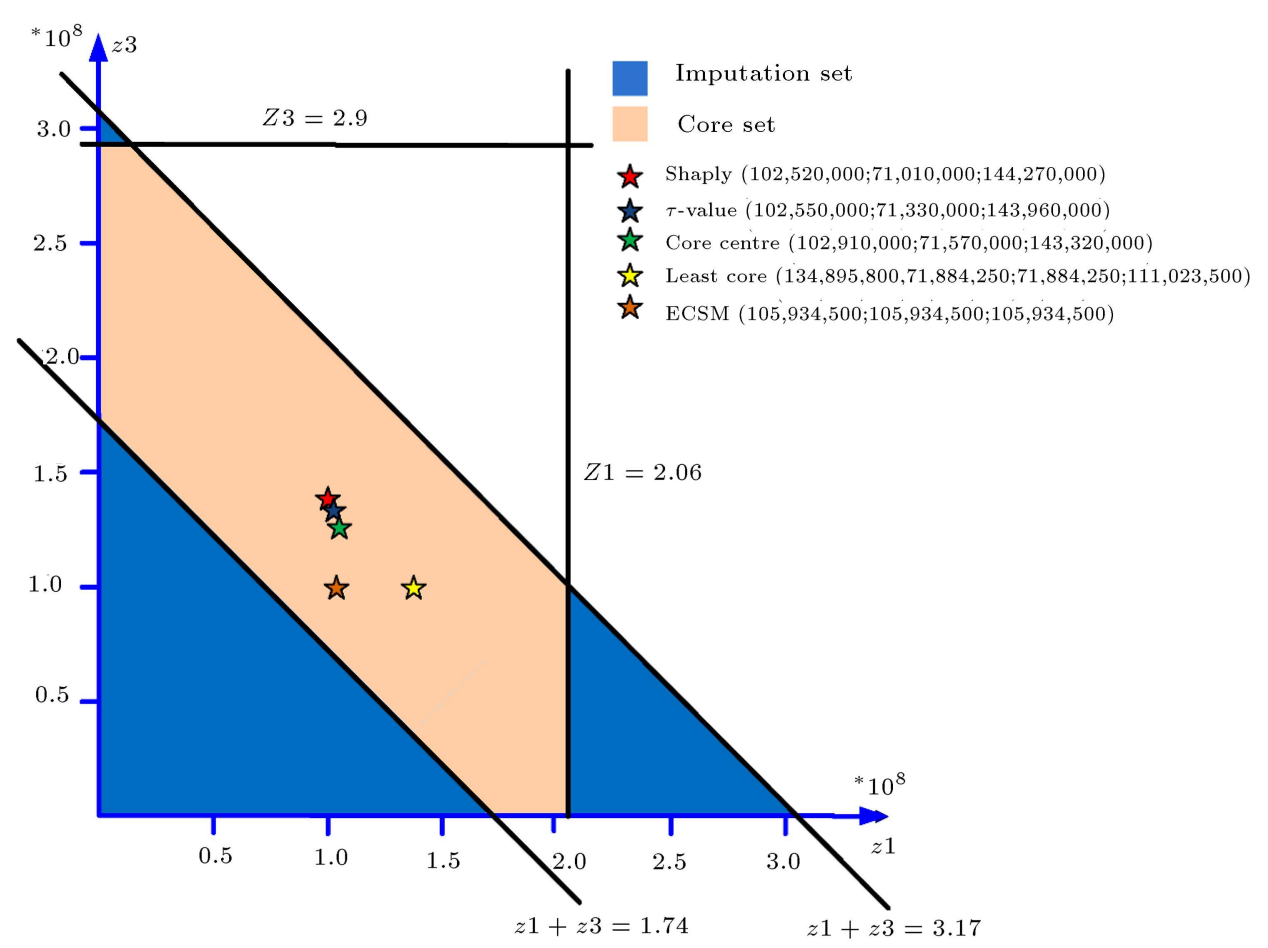

Figure 5. Core Solution (CS) of three different factories.

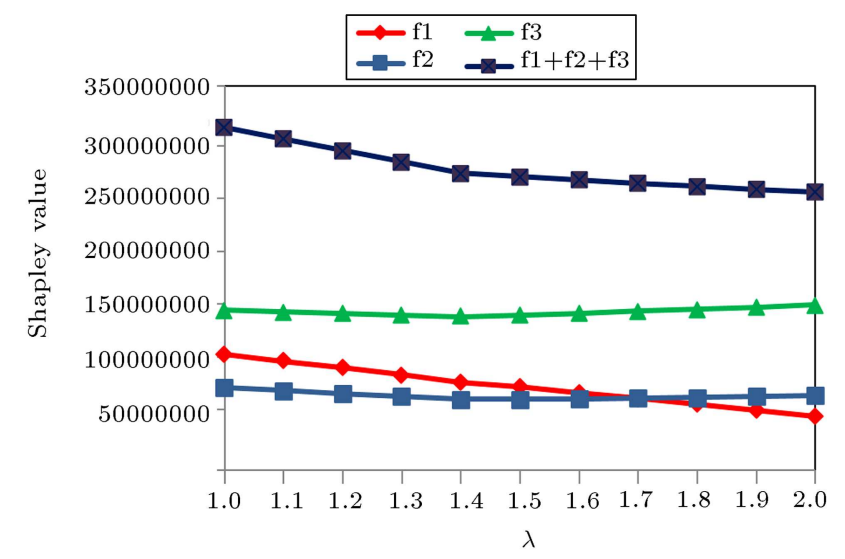

Figure 6. Sensitivity analysis of the Shapley values with respect to the changes in intra-factory transportation cost (with coefficient $\lambda$ ).

changing the core set, as shown in Figure 7. This figure also depicts four core sets for different $\lambda$-values $(\lambda=$ $1,1.4,1.8$, and 2). Based on this figure, we find that the core set of the Co-CMS shrinks when increasing the intra-factory transportation costs. The Shapely values are also demonstrated in each core set [24].

In Table 9 , the revenue, cost, and profit of each possible coalition are reported when the companies supply different percentages of the Mega Motor's demand. The companies can improve their profit by controlling their production cost through cooperation. According to Figure 8, when companies completely use their capacity, they can decrease their overload costs. In case the three companies cooperate to share their excess capacities and supply a larger portion of the Mega Motor's demand, then they can gain greater earnings.

The numerical example provides us with the following managerial insights:

- In the Co-CMS, the semi-finished products can be freely transported among the cooperating companies. Therefore, the Co-CMS may give a completely different solution relative to multi-site CMS with nocooperation. The intra-factory transportation cost is a key factor in effective cooperation in Co-CMS;

- In Co-CMS, the cooperating companies may share the capacities of machines and reduce the production cost. Hence, cooperation between the companies can improve their competitive advantage. For example, three suppliers of Mega Motor can effectively supply a large proportion of its demand through cooperation;

- When the intra-factory cost of a cooperating company in Co-CMS increases, it negatively affects the cost of the whole system. Moreover, the company will gain lower share from total cost-saving due to its low effectiveness;

- Different cost-saving methods yield different assignments; however, Shapley, $\tau$-value, and Core center methods offer similar solutions in the given case study. The best method should be selected based on the satisfaction of cooperating companies because 

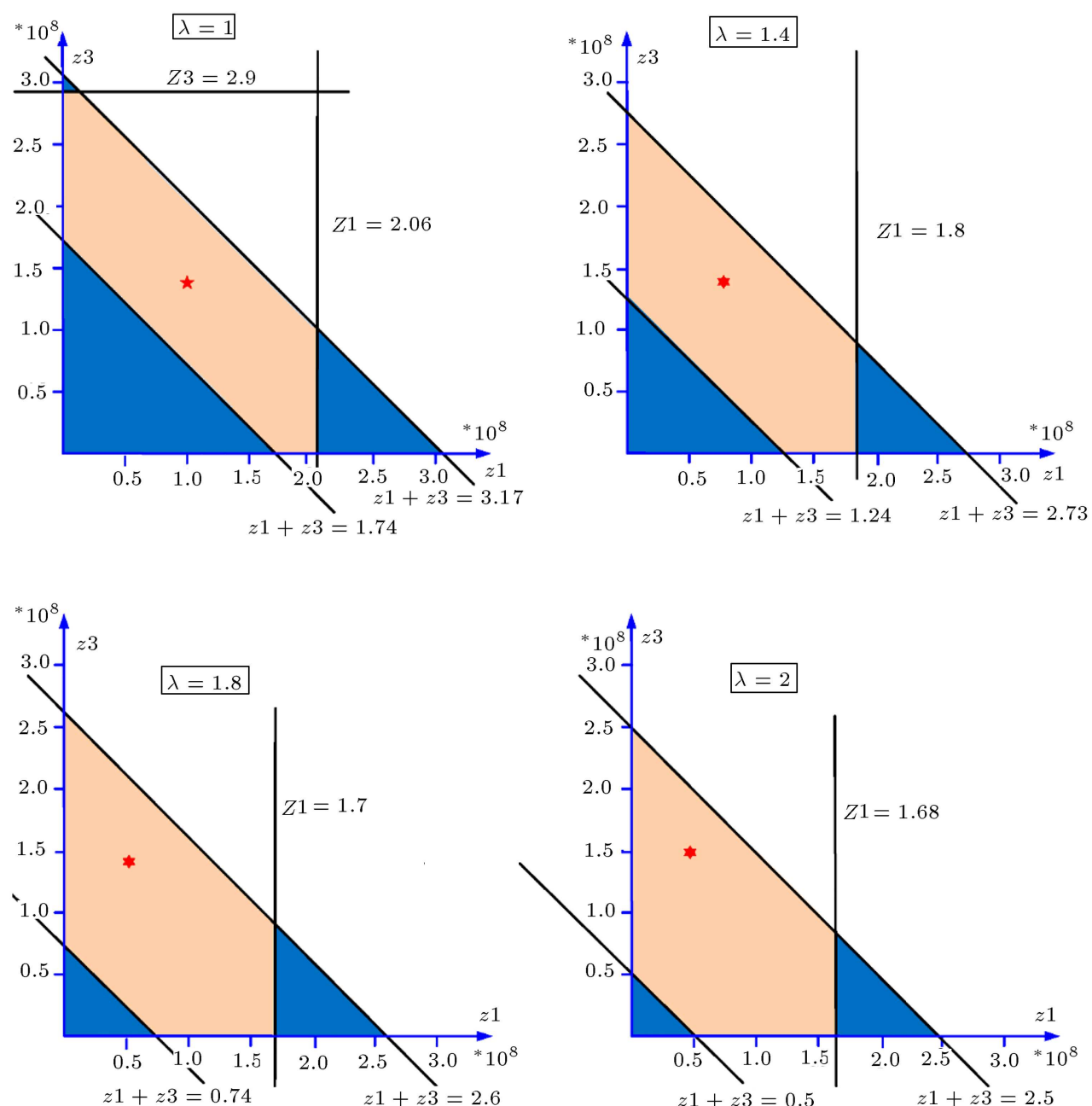

Figure 7. The changes in core set with respect to the increases in intra-factory cost (with coefficient $\lambda$ ).
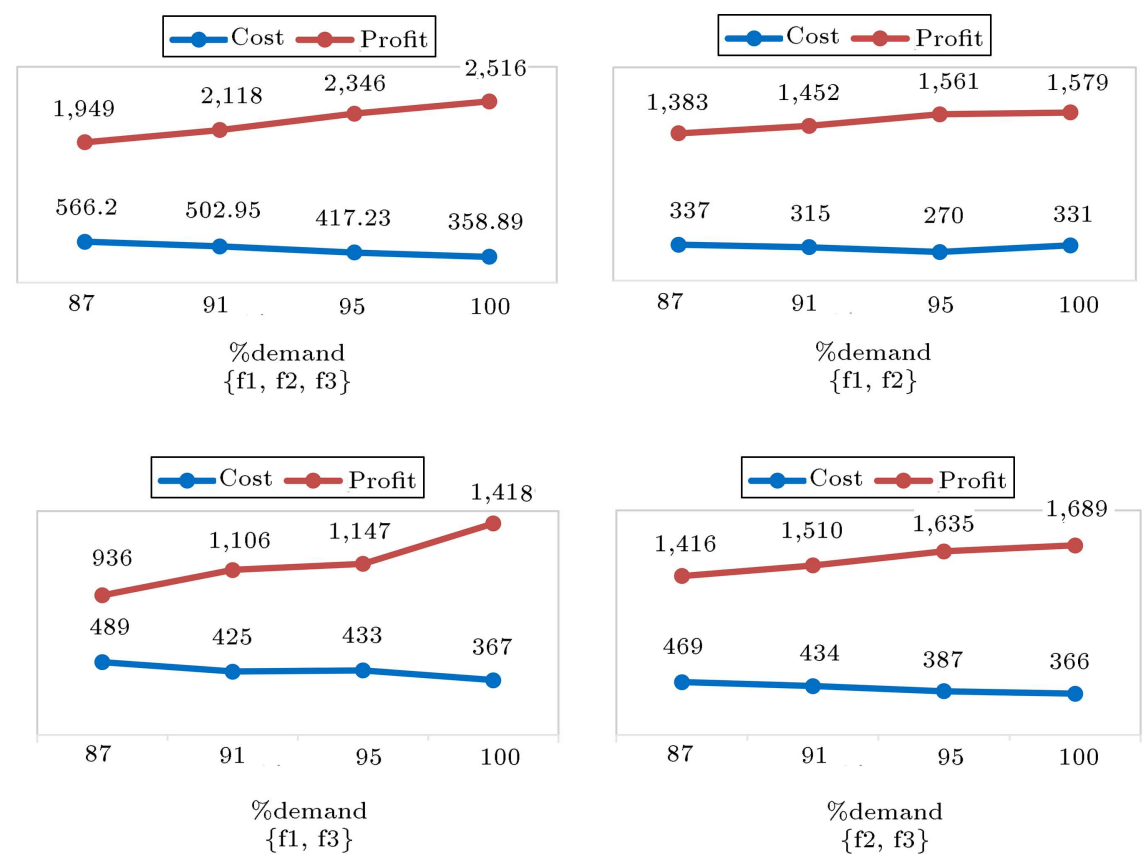

Figure 8. Changing of profit and cost for each possible coalition by supplying different percentages of demand. 
Table 9. Detailed data of revenue, cost, and profit for each coalition.

\begin{tabular}{|c|c|c|c|c|c|}
\hline Coalition $S$ & & $87 \%$ & $91 \%$ & $95 \%$ & $100 \%$ \\
\hline \multirow{3}{*}{$\mathrm{f} 1$} & Revenue & $630,000,000$ & $676,700,000$ & $740,600,000$ & NA \\
\hline & Cost & $223,200,000$ & $240,070,000$ & $262,820,000$ & NA \\
\hline & profit & $406,800,000$ & $436,630,000$ & $477,780,000$ & NA \\
\hline \multirow{3}{*}{$\mathrm{f} 2$} & Revenue & $1,090,000,000$ & $1,090,000,000$ & $1,090,000,000$ & $1,090,000,000$ \\
\hline & Cost & $135,490,000$ & $135,490,000$ & $135,490,000$ & $135,490,000$ \\
\hline & profit & $954,510,000$ & $954,510,000$ & $954,510,000$ & $954,510,000$ \\
\hline \multirow{3}{*}{ f3 } & Revenue & $795,000,000$ & NA & NA & NA \\
\hline & Cost & $318,000,000$ & NA & NA & NA \\
\hline & profit & $477,000,000$ & NA & NA & NA \\
\hline \multirow{3}{*}{$\mathrm{f} 1-\mathrm{f} 2$} & Revenue & $1,720,000,000$ & $1,766,700,000$ & $1,830,600,000$ & $1,910,000,000$ \\
\hline & Cost & $337,260,000$ & $314,800,000$ & $269,860,000$ & $331,180,000$ \\
\hline & profit & $1,382,740,000$ & $1,451,900,000$ & $1,560,740,000$ & $1,578,820,000$ \\
\hline \multirow{3}{*}{ f1-f3 } & Revenue & $1,425,000,000$ & $1,531,150,000$ & $1,580,280,000$ & $1,785,000,000$ \\
\hline & Cost & $488,620,000$ & $425,370,000$ & $432,860,000$ & $367,170,000$ \\
\hline & profit & $936,380,000$ & $1,105,780,000$ & $1,147,420,000$ & $1,417,830,000$ \\
\hline \multirow{3}{*}{$\mathrm{f} 2-\mathrm{f} 3$} & Revenue & $1,885,000,000$ & $1,944,450,000$ & $2,022,350,000$ & $2,055,000,000$ \\
\hline & Cost & $469,490,000$ & $434,320,000$ & $387,370,000$ & $365,740,000$ \\
\hline & profit & $1,415,510,000$ & $1,510,130,000$ & $1,634,980,000$ & $1,689,260,000$ \\
\hline \multirow{3}{*}{ f1-f2-f3 } & Revenue & $2,515,000,000$ & $2,621,150,000$ & $2,762,950,000$ & $2,875,000,000$ \\
\hline & Cost & $566,200,000$ & $502,950,000$ & $417,230,000$ & $358,890,000$ \\
\hline & profit & $1,948,800,000$ & $2,118,200,000$ & $2,345,720,000$ & $2,516,110,000$ \\
\hline
\end{tabular}

a fair assignment of cost-savings encourages the companies to continue their cooperation in Co-CMS.

\section{Conclusion and further research}

This study established a mathematical programming model for Cooperative Cellular Manufacturing System (Co-CMS) to formulate the cooperative manufacturing problem. Through the application of the coalition concept of Cooperative Game Theory (CGT), we found that when cooperating companies with Cellular Manufacturing System (CMS) technology formed a coalition, they could reduce the cost by sharing the capacities. In fact, the synergy derived from the cooperation offers some incentives for the companies to organize large coalitions. Successful implementation of Co-CMS depends on a fair assignment of cost-savings of collaboration, which motivates the companies to maintain their cooperation. Thus, we proposed a set of solution methods including the Shapley value, $\tau$ - value, least core, and core center to distribute costsavings of Co-CMS among cooperating companies in a fair manner. To obtain an insight into the problem and examine the behavior of the proposed solution methods, a real case study of the Mega Motor Company was thoroughly evaluated in which its three suppliers including Saipa-Piston, Behran-Mehvar, and Saipa-Polos with CMS technology planned to work together.

Several issues can be suggested for further research. In the model proposed in this study, some assumptions were taken into consideration; for instance, the companies manufacture similar products with the same operation. Eliminating these assumptions and adding the workers' limitation to the proposed model would also be interesting. Moreover, considering virtual cells is significantly important. It was assumed in this study that all the players were ready to share the whole extra capacities. However, there may be 
companies that wish to share just a part of their extra capacity and studying Co-CMS in this situation would be very interesting. Moreover, analyzing the Co-CMS in an uncertain environment can be further studied in the future researches.

\section{References}

1. Aalaei, A. and Davoudpour, H. "A robust optimization model for cellular manufacturing system into supply chain management", International Journal of Production Economics, Elsevier, 183(PC), pp. 667-679 (2016).

2. Chalkiadakis, G., Elkind, E., and Wooldridge, M. "Cooperative game theory basic concepts and computational challenges", IEEE Intelligent Systems, 27(3), pp. 86-90 (2012).

3. Sayadi, M.K., Hafezalkotob A., and Naini, S.G.J. "Fired-inspired algorithm for discrete optimization problems: an application to manufacturing cell formation", Journal of Manufacturing System, 32(1), pp. 78-84 (2013).

4. Singh, N. "Design of cellular manufacturing systems: an invited review", European Journal of Operational Research, 69, pp. 284-291 (1993).

5. Wemmerlov, U. and Johnson, D.J. "Cellular manufacturing at 46 user plants: Implementation experiences and performance improvements", International Journal of Production Research, 35, pp. 29-49 (1997).

6. Dimopoulos, C. and Zalzala, A.M. "Recent developments in evolutionary computation for manufacturing optimization: problems, solutions, and comparisons", IEEE Transactions on Evolutionary Computation, 4(2), pp. 93-113 (2000).

7. Akturk, M.S. and Turkcan, A. "Cellular manufacturing system design using a holistic approach", International Journal of Production Research, 38(10), pp. 2327-2347 (2000).

8. Mahdavi, I. and Mahadevan, B. "CLASS: An algorithm for cellular manufacturing system and layout design using sequence data", Robotics and ComputerIntegrated Manufacturing, 24(3), pp. 488-497 (2008).

9. Defersha, F.M. and Chen, M. "A comprehensive mathematical model for the design of cellular manufacturing systems", International Journal of Production Economics, 103(2), pp. 767-783 (2006).

10. Ahkioon, S., Bulgak, A.A., and Bektas, T. "Cellular manufacturing systems design with routing flexibility, machine procurement, production planning and dynamic system reconfiguration", International Journal of Production Research, 47(6), pp. 1573-1600 (2009).

11. Kia, R., Khaksar-Haghani, F., Javadian, N., and Tavakkoli-Moghaddam, R. "Solving a multi-floor layout design model of a dynamic cellular manufacturing system by an efficient genetic algorithm", Journal of Manufacturing Systems, 33(1), pp. 218-32 (2014).
12. Kia, R., Baboli, A., Javadian, N., TavakkoliMoghaddam, R., Kazemi, M., and Khorrami, J. "Solving a group layout design model of a dynamic cellular manufacturing system with alternative process routings, lot splitting and flexible reconfiguration by simulated annealing", Computers \& Operations Research, 39(11), pp. 2642-58 (2012).

13. Tavakkoli-Moghaddam, R., Javadian, N., Javadi, B., and Safaei, N. "Design of a facility layout problem in cellular manufacturing systems with stochastic demands", Applied Mathematics and Computation, 184(2), pp. 721-8 (2007).

14. Wang, T.Y., Wu, K.B., and Liu, Y.W. "A simulated annealing algorithm for facility layout problems under variable demand in cellular manufacturing systems", Computers in Industry, 46(2), pp. 181-8 (2001).

15. Wang, S. and Sarker, B.R. "Locating cells with bottleneck machines in cellular manufacturing systems", International Journal of Production Research, 40(2), pp. 403-24 (2002).

16. Bagheri, M. and Bashiri, M. "A new mathematical model towards the integration of cell formation with operator assignment and inter-cell layout problems in a dynamic environment", Applied Mathematical Modelling, 38(4), pp. 1237-54 (2014).

17. Chen, M. and Cao D. "Coordinating production planning in cellular manufacturing environment using Tabu search", Computers \& Industrial Engineering, 46(3), pp. 571-88 (2004).

18. Safaei, N., Saidi-Mehrabad, M., and Jabal-Ameli, M.S. "A hybrid simulated annealing for solving an extended model of dynamic cellular manufacturing system", European Journal of Operational Research, 185(2), pp. 563-92 (2008).

19. Mahdavi, I., Aalaei, A., Paydar, M.M., and Solimanpur, M. "Designing a mathematical model for dynamic cellular manufacturing systems considering production planning and worker assignment", Computers \& Mathematics with Applications, 60(4), pp. 1014-25 (2010).

20. Safaei, N. and Tavakkoli-Moghaddam, R. "Integrated multi-period cell formation and subcontracting production planning in dynamic cellular manufacturing systems", International Journal of Production Economics, 120(2), pp. 301-14 (2009).

21. Saidi-Mehrabad, M. and Safaei, N. "A new model of dynamic cell formation by a neural approach", International Journal Advance Manufacturing Technology, 33, pp. 1001-1009 (2007).

22. Schaller, J. "Designing and redesigning cellular manufacturing system to handle demand changes", Computer \& Industrial Engineering, 53, pp. 478-490 (2007).

23. Frisk, M., Göthe-Lundgren, M., Jörnsten, K., and Rönnqvist, M. "Cost allocation in collaborative forest transportation", European Journal of Operational Research, 205(2), pp. 448-58 (2010). 
24. Lozano, S., Moreno, P., Adenso-Díaz, B., and Algaba, E. "Cooperative game theory approach to allocating benefits of horizontal cooperation", European Journal of Operational Research, 229(2), pp. 444-52 (2013).

25. Hafezalkotob, A. and Makui, A. "Cooperative maximum-flow problem under uncertainty in logistic networks", Applied Mathematics and Computation, 250, pp. 593-604 (2015).

26. Mohebbi, S. and Li, X. "Coalitional game theory approach to modeling suppliers' collaboration in supply networks", International Journal of Production Economics, 169, pp. 333-42 (2015).

27. Zibaei, S., Hafezalkotob, A., and Ghashami, S.S. "Cooperative vehicle routing problem: an opportunity for cost saving", Journal of Industrial Engineering International, 12, pp. 1-16 (2016).

28. Sakawa, M., Nishizaki, I., and Uemura, Y. "Fuzzy programming and profit and cost allocation for a production and transportation problem", European Journal of Operational Research, 131(1), pp. 1-5 (2001).

29. Curiel, I., Potters, J., Prasad, R., Tijs, S., and Veltman, B. "Cooperation in one machine scheduling", Operations Research, 38(2), pp. 113-29 (1993).

30. Mohammaditabar, D., Ghodsypour, S.H., and Hafezalkotob, A. "A game theoretical analysis in capacityconstrained supplier-selection and cooperation by considering the total supply chain inventory costs", International Journal of Production Economics, 181, pp. 87-97 (2016).

31. Dai, Z., Liu, X.C., Chen, Z., Guo, R., and Ma, X. "A predictive headway-based bus-holding strategy with dynamic control point selection: A cooperative game theory approach", Transportation Research Part B: Methodological, 125, pp. 29-51 (2019).

32. Barron, E.N., Game Theory: An Introduction, 2nd Edition, John Wiley \& Sons (2013).

33. Drechsel, J. and Kimms, A. "Computing core allocations in cooperative games with an application to cooperative procurement", International Journal of Production Economics, 128(1), pp. 310-321 (2010).

34. Tijs, S.H. and Driessen, T.S. "Game theory and cost allocation problems", Management Science, 32(8), pp. 1015-28 (1986).

35. Mirás Calvo, M.A. and Sánchez Rodríguez, E. "TUGlab: A cooperative game theory toolbox", $<$ http //websuvigoes/mmiras/TUGlab/TUGl abICM06pdf $>$ (accessed 080113) (2006).

36. Shapley, L.S. "A value for n-person games", Ann. Math. Stud, pp. 307-317 (1953).

37. Shapley, L.S. "Cores of convex games", International Journal of Game Theory, 1(1), pp. 11-26 (1971).

38. Fardi, K., Jafarzadeh Ghoushchi, S., and Hafezalkotob, A. "An extended robust approach for a cooperative inventory routing problem", Expert Systems with Applications, 116, pp. 310-327 (2019).
39. Zhang, C., You, M., and Han, G. "Supply chain decisions with credit-linked demand by stackelberg game models", Scientia Iranica, 28(2), pp. 927-949 (2019). DOI: $10.24200 /$ sci.50342.1646

40. Baogui, X., and Minghe, S. "A differential oligopoly game for optimal production planning and water savings", European Journal of Operational Research, 269, pp. 206-217 (2017).

41. Roberto, C. and Lambertini, L. "A differential oligopoly game with differentiated goods and sticky prices", European Journal of Operational Research, 176(2), pp. 1131-1144 (2007).

42. René, A.O.N., Tanizaki, T., Ueno, N., Domoto, E., and Okuhara, K. "Coalitional game-theoretic model for inventory management", ICIC Express Letters, 12(8), pp. 805-811 (2018).

43. Nazari, L., Seifbarghy, M., and Setak, M. "Modeling and analyzing pricing and inventory problem in a closed-loop supply chain with return policy and multiple manufacturers and multiple sales channels using game theory", Scientia Iranica, 25(5), pp. 2759-2774 (2017). DOI: $10.24200 /$ sci.2017.4459

44. Fiestras-Janeiro, M.G., García-Jurado, I., Meca. A., and Mosquera, M.A. "Cooperative game theory and inventory management", European Journal of Operational Research, 210(3), pp. 459-466 (2011).

45. Gutierrez, E., Llorca, N., Mosquera, M., and SanchezSoriano, J. "On horizontal cooperation in linear production processes with a supplier, that controls a limited resource", Mathematical Methods of Operations Research, 90(2), pp. 1-28 (2019).

46. He, Q.C., Chen, Y.J., and Shen, Z.J. "On the formation of producers' information-sharing coalitions", Production and Operations Management, 27(5), pp. 917-927 (2018).

47. Ghashghaei, H. and Mozafari, M. "A game theoretic approach to coordinate pricing, ordering and co-op advertising in supply chains with stochastic demand", Scientia Iranica, E, 27(6), pp. 3289-3304 (2020). DOI: 10.24200/sci.2019.51588.2264

48. Le, P.H., Nguyen, T.D., and Bektaş, T. "Efficient computation of the Shapley value for large-scale linear production games", Annals of Operations Research, 287, pp. 761-781 (2020).

49. Wu, Y., Zheng, M., He, M., Zhang, D., He, W., Hua, B., and Wang, F. "Cooperative game theory-based optimal angular momentum management of hybrid attitude control actuator", IEEE Access, 7, pp. 68536865 (2018).

50. Chao, G.E.N.G., Shiyou, Q.U., Yingying, X.I.A.O., Mei, W.A.N.G., Guoqiang, S.H.I., Tingyu, L.I.N., and Zhengxuan, J.I.A. "Diffusion mechanism simulation of cloud manufacturing complex network based on cooperative game theory", Journal of Systems Engineering and Electronics, 29(2), pp. 321-335 (2018). 


\section{Biographies}

Maryam Tavanayi received her BSc degree in Industrial Engineering in 2013 from Sharif University and her MSc degree in Industrial Engineering in 2017 at the Industrial Engineering College of South Tehran Branch of Islamic Azad University. Her research interests include supply chain, decision-making techniques, game theory, and mathematical modelling.

Ashkan Hafezalkotob is currently an Associate Professor at the Industrial Engineering College of South Tehran Branch of Islamic Azad University. He received his BSc degree in Industrial Engineering in 2004, MSc degree in Industrial Engineering in 2007, and PhD in Industrial Engineering in 2012 at Iran University of Science and Technology. His research interests include supply chain, decision-making techniques, game theory, and mathematical modelling. He has authored several papers published in different National and international journals and conferences proceedings.

Jaber Valizadeh is currently a $\mathrm{PhD}$ student at the Industrial Management College of Saveh Branch of Islamic Azad University. He received his BSc degree in Applied Mathematics in 2010 and MSc degree in Industrial Management in 2013. His research interests include supply chain, waste management, energy, game theory, and mathematical modelling. He has authored papers published in several journals including Alexandria Engineering Journal, and some other journals and conference proceedings. He has also published two books on supply chain management and risk quantitative analysis. 